\title{
Any closer to successful therapy of multiple myeloma? CAR-T cell is a good reason for optimism
}

\author{
Faroogh Marofi ${ }^{1}$, Safa Tahmasebi ${ }^{2}$, Heshu Sulaiman Rahman ${ }^{3}$, Denis Kaigorodov ${ }^{4}$, Alexander Markov ${ }^{5}$, \\ Alexei Valerievich Yumashev ${ }^{6}$, Navid Shomali ${ }^{7,8}$, Max Stanley Chartrand ${ }^{9}$, Yashwant Pathak ${ }^{10,11}$, \\ Rebar N. Mohammed ${ }^{12}$, Mostafa Jarahian ${ }^{13}$, Roza Motavalli ${ }^{14^{*}}$ and Farhad Motavalli Khiavi ${ }^{15^{*}}$
}

\begin{abstract}
Despite many recent advances on cancer novel therapies, researchers have yet a long way to cure cancer. They have to deal with tough challenges before they can reach success. Nonetheless, it seems that recently developed immunotherapy-based therapy approaches such as adoptive cell transfer (ACT) have emerged as a promising therapeutic strategy against various kinds of tumors even the cancers in the blood (liquid cancers). The hematological (liquid) cancers are hard to be targeted by usual cancer therapies, for they do not form localized solid tumors. Until recently, two types of ACTs have been developed and introduced; tumor-infiltrating lymphocytes (TILs) and chimeric antigen receptor (CAR)-T cells which the latter is the subject of our discussion. It is interesting about engineered CAR-T cells that they are genetically endowed with unique cancer-specific characteristics, so they can use the potency of the host immune system to fight against either solid or liquid cancers. Multiple myeloma (MM) or simply referred to as myeloma is a type of hematological malignancy that affects the plasma cells. The cancerous plasma cells produce immunoglobulins (antibodies) uncontrollably which consequently damage the tissues and organs and break the immune system function. Although the last few years have seen significant progressions in the treatment of $\mathrm{MM}$, still a complete remission remains unconvincing. MM is a medically challenging and stubborn disease with a disappointingly low rate of survival rate. When comparing the three most occurring blood cancers (i.e., lymphoma, leukemia, and myeloma), myeloma has the lowest 5-year survival rate (around $40 \%$ ). A low survival rate indicates a high mortality rate with difficulty in treatment. Therefore, novel CAR-T cell-based therapies or combination therapies along with CAT-T cells may bring new hope for multiple myeloma patients. CAR-T cell therapy has a high potential to improve the remission success rate in patients with MM. To date, many preclinical and clinical trial studies have been conducted to investigate the ability and capacity of CAR T cells in targeting the antigens on myeloma cells. Despite the problems and obstacles, CAR-T cell experiments in MM patients revealed a robust therapeutic potential. However, several factors might be considered during CAR-T cell therapy for better response and reduced side effects. Also, incorporating the CAT-T cell method into a (Continued on next page)
\end{abstract}

\footnotetext{
*Correspondence: Rozamotavalli@gmail.com; farhad.motavalli@gmail.com

${ }^{14}$ Stem Cell Research Center, Tabriz University of Medical Sciences, Tabriz,

Iran

${ }^{15}$ Department of Virology, Pasteur Institute of Iran, Tehran, Iran

Full list of author information is available at the end of the article
}

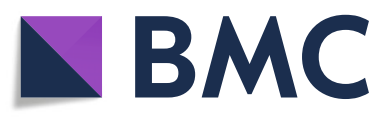

(c) The Author(s). 2021 Open Access This article is licensed under a Creative Commons Attribution 4.0 International License, which permits use, sharing, adaptation, distribution and reproduction in any medium or format, as long as you give appropriate credit to the original author(s) and the source, provide a link to the Creative Commons licence, and indicate if changes were made. The images or other third party material in this article are included in the article's Creative Commons licence, unless indicated otherwise in a credit line to the material. If material is not included in the article's Creative Commons licence and your intended use is not permitted by statutory regulation or exceeds the permitted use, you will need to obtain permission directly from the copyright holder. To view a copy of this licence, visit http://creativecommons.org/licenses/by/4.0/. The Creative Commons Public Domain Dedication waiver (http://creativecommons.org/publicdomain/zero/1.0/) applies to the data made available in this article, unless otherwise stated in a credit line to the data. 
(Continued from previous page)

combinational treatment schedule may be a promising approach. In this paper, with a greater emphasis on CAR-T

cell application in the treatment of MM, we will discuss and introduce CAR-T cell's history and functions, their

limitations, and the solutions to defeat the limitations and different types of modifications on CAR-T cells.

Keywords: Multiple myeloma, Adoptive cell therapy, CAR-T cells, Hematological malignancy

\section{Introduction}

Multiple myeloma (MM) is the second most prevalent hematological cancer that attributes to a plasma cell malignancy specified by the increased proliferation of mutated plasma cells. Microenvironment variation in bone marrow, plasma cell mutations, and immune surveillance disability are the main causes for monoclonal gammopathy of undetermined significance (MGUS) and multiple myeloma [1, 2]. In this regard, several therapeutic approaches have been assigned for treating MM patients, including immunomodulatory drugs (IMiDs), monoclonal antibodies, donor lymphocyte infusions (DLIs), and allogeneic stem cell transplantation (allo-SCT). However, the curability and prognosis of the patients mostly remain poor in relapsed and refractory (RR) MM patients $[1,3]$. Approximately, 3 years of median overall survival have been reported in higher stage and high-risk cytogenetics patients [4]. Currently, significant steps have been taken towards the development of immunotherapybased drugs for treating patients with multiple myeloma. Monoclonal antibodies, checkpoint inhibitors, antibodydrug conjugations, bispecific $\mathrm{T}$ cell engagers (BiTEs), and adoptive $\mathrm{T}$ cell therapy (ACT) are examples of immune-based therapies that have been expanded for MM treatment. Beneficially, daratumumab and elotuzumab are FDA-approved monoclonal antibodies that have been indicated to strengthen the immune system to target the MM cells $[5,6]$.

Nowadays, the ACT has been shown impressive results in cancer treatment among immunotherapy approaches by boosting the immune system response. The ACT is performed to transfer the manipulated autologous cells into patients' bodies [7]. During the last decade, genetically engineered chimeric antigen receptor (CAR)- $\mathrm{T}$ cell therapy has been identified as an advanced subgroup of $\mathrm{ACT}$ for treating cancers, infections, and allergic disorders $[8,9]$. Hopefully, CAR-T cell therapy has illustrated the beneficial implications in hematological malignancies [10]; however, barriers in solid tumors cause CAR-T cells to become ineffective [11]. CAR-T cells are generated by transferring the manipulated gene into $\mathrm{T}$ cells. CAR-T cell comprises the recombinant antigen receptor that binds to the target antigens, and the $\mathrm{T}$ cell signaling portion which activates the $\mathrm{T}$ cells. Besides, this synthetic CAR-T cell possesses the antigen recognition ability in a non-MHC-dependent method. In comparison with conventional T cells expressing TCR, CAR-T cells are characterized by several benefits, including simple structure, targeting various types of antigens to overcome the tumor escape, more significant anti-tumor cytotoxicity, proliferation as well as persistence in determining tumor sites $[12,13]$.

Since the hypothesis of CAR-T was firstly presented in the late 1980s, many supported preclinical and clinical studies have been carried out to evaluate the capability of engineered $\mathrm{T}$ cells in diverse hematological malignancies. CD19, CD20, CD30, and CD138 are the most predominant target antigens found in different species of hematological cancers. CD19, a prevalent surface marker on B cell, is used to engineer the anti-CD19 CAR-T cell which was approved by US Food and Drug Administration (FDA) for treating diffuse large $\mathrm{B}$ cell lymphoma (DLBCL) and acute lymphocytic leukemia (ALL) diseases $[14,15]$. CAR-T cell therapy as a promising therapeutic method for multiple myeloma was first developed for ALL, CLL, and DLBCL malignancies.

The success of immunotherapy approaches, like CAR$\mathrm{T}$ cell therapy, requires the severe and selective expression of target antigens on tumor cells along with their non-expression on normal cells. The clinical studies have identified several numbers of target antigens expressed on abnormal plasma cells in multiple myeloma, including CD19, CD38, CD138, SLAMF7, kappa light chain, $\mathrm{B}$ cell maturation antigen (BCMA), and SLAMF7. In the current study, we aimed to demonstrate a comprehensive overview of the immunotherapy approaches for treating multiple myeloma by focusing on up-to-date knowledge on various CAR-T cells designed for targeting different target antigens on abnormal plasma cells in multiple myeloma.

\section{Immunotherapy therapeutic approaches in multiple myeloma disease}

Allogeneic stem cell transplantation (allo-SCT)

The allo-SCT is the first line cell therapy method in multiple myeloma, leading to longstanding progressionfree survival (PFS), and curative graft-versus-myeloma (GvM) influences. Despite the potent remedial role with up to $50 \%$ remission rate, the allo-SCT is limited due to the upward trend of non-relapse mortality (NRM) rate of approximately $40-60 \%$ [16]. There are also significant adverse effects related to allo-SCT, including greater 
morbidity and mortality rate, infection risk, immunosuppression, and graft-versus-host disease (GVHD), all of which have restricted its application [17].

\section{Monoclonal antibodies}

Monoclonal antibodies (mAbs), as pivotal therapeutic approaches, have been designed to overcome exclusively target antigens overexpressed on abnormal plasma cells in multiple myeloma, but not on normal cells [18]. To eradicate the tumor cells, antibodies trigger the antibody-dependent cellular cytotoxicity (ADC) along with the complement-dependent cytotoxicity (CDC), both of which lead to the secretion of cytotoxic components after binding to targets [19]. In this regard, there are no pieces of evidence showing their involvement in tumor cell eradication in MM unless when used in combination with IMiDs, proteasome inhibitors, and corticosteroids [20]. mAbs in multiple myeloma have been generated against CD38, CD40, CD56, CD74, CD138, SLAMF7, KIR, and PD-1 target antigens, two of which are applicable and FDA-approved for treating patients with MM, including daratumumab (Anti-CD38 mAb) and elotuzumab (Anti-SLAMF7 MAb) [21].

\section{Antibody-drug conjugates (ADCs)}

Antibody-drug conjugates (ADCs) are composed of mAbs conjugating to anti-tubulin cytotoxic factors. These antibodies detect and subsequently bind to the target antigens which accelerate the eradication of tumor cells through the toxin agents releasing into the tumor microenvironment. In phase I/II studies, an anti-CD138 $\mathrm{ADC}$ (indatuximab ravtansine) along with lenalidomide and dexamethasone have been shown promising results with approximately $78 \%$ objective response rate (ORR) [22].

\section{Bispecific $T$ cell engagers (BiTE)}

Bispecific $\mathrm{T}$ cell engagers (BiTE), or bispecific antibodies, are constituted of a recombinant antibody with specificity for two distinct epitopes, such as CD3 on the T cells and target antigen on the myeloma cells. $\mathrm{T}$ cell activation and functionalization are mediated by simultaneous transplantation between two epitopes and BiTE on tumor cells [23]. It has been revealed that the constant development of this approach provides the redirection of a large number of $\mathrm{T}$ cells into the tumor microenvironment. CD138- and CD3-specific antibodies are the example of BiTE produced for MM treatment [24].

\section{Checkpoint inhibitors}

Programmed cell death protein ligand-1 (PD-L1) is expressed on tumor cells, applying the inhibitory function against the effector role of the $\mathrm{T}$ cells by binding to PD-1 which is expressed on T cells [25]. PD-L1 is upregulated at both relapse or refractory phase of MM. A great population of $\mathrm{PD}-\mathrm{L} 1^{+} \mathrm{MM}$ cells along with their high resistance to anti-myeloma factors has been demonstrated in patients with MM [26]. Nivolumab, an antiPD-L1 monoclonal antibody, has shown objective responses in phase I clinical trial with approximately $63 \%$ responsiveness among 27 patients, and overall survival of 11.4 weeks in relapsed/refractory MMs [27]. Moreover, in phase II of a clinical trial, beneficial outcomes of integrative therapy have been implied in patients with MM using anti-PD-L1 antibodies (pembrolizumab and pomalidomide), and dexamethasone [28]. Since there are no reported controversial reactions of the checkpoint blockade immunotherapy in treating patients with multiple myeloma, it may be successful in combination with other therapies.

\section{Vaccines}

Several known peptides or dendritic cell-based vaccines are used to build long-term memory against disease recurrence by boosting host immunity and increasing tumor-specific lymphocytes [21]. In this regard, peptidebased vaccines have been administered for MM patients to induce the myeloma-associated antigens on plasma cells, resulting in the expansion of effector $\mathrm{T}$ cell repercussions. Multiepitope peptide vaccines have been developed to overcome remarkably various target antigens. For instance, CD138, X-box binding protein 1 (XBP1), and connecting segment 1 (CS-1) peptides are multiepitope vaccines that have elicited an influential effect on the $\mathrm{T}$ cell activity, resulting in the eradication of myeloma cells in vitro [29]. This kind of vaccine revealed robust immune responses in an examination of smoldering MM patients [30]. Furthermore, a dendritic cell-based vaccine has been shown to be useful in treating patients with MM. This method can be established by the fusion of patient-derived myeloma cells with autologous dendritic cells. Promising results have implied that usage of the dendritic/myeloma cell-based vaccine in the phase I/ II trials conducts to an increase in the frequency of $\mathrm{CD} \mathrm{b}^{+}$and $\mathrm{CD} \mathrm{b}^{+}$myeloma specific T cells $[31,32]$.

\section{Adoptive cell therapy (ACT)}

The ACT has emerged to promote the performance of effector cells in targeting antigens and eradicating the tumor cells by ex vivo manipulations. Also, the ACT isolates autologous $\mathrm{T}$ cells by leukapheresis, reinfusing the ex vivo engineered and cultivated cells into patient's bodies. Three main ACT-based approaches have been comprised of several forms, including $\mathrm{T}$ cell receptor (TCR)-engineered $\mathrm{T}$ cells, autologous tumor-infiltrating lymphocytes (TILs), marrow infiltrating lymphocytes (MILs), $\gamma \delta \mathrm{T}$ cells, CAR (chimeric antigen receptor)-T cells, and NK cells. They have been specifically 
developed for MM immunotherapy [33]. In this study, we predominantly focused on different CAR-T cell therapies in MM malignancy.

\section{Chimeric antigen receptor-T cell}

Broad utilization of the engineered chimeric antigen receptor (CAR)-T cells have taken a great step forward in cancer immunotherapy, especially in hematological malignancies. So far, CAR-T cell therapy has been intemperately studied in varying preclinical and clinical investigations [34-38]. To engineer CAR-T cells, $\mathrm{T}$ cells should manipulate for expressing CAR genes by viral vectors [39]. There are also several examined transferring techniques, including CRISPR/Cas9 gene-editing strategy [40], electroporation [41], and liposomes [42]. CAR-T cells could significantly dominate conventional TCR restrictions, for instance, HLA-dependent limitations, defined specificity for peptide antigens, limited applications, lower cytotoxicity, persistence, and proliferation.

Modified TCR-like molecules (CAR) have been comprised of single-chain variable fragments $(\mathrm{ScFv})$ as an extracellular domain, spacer (CD4, CD8, or IgG4 Fc), a

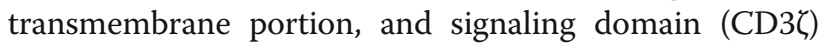
with or without the presence of costimulatory domains (CD28, 4-1BB, or OX40) [11, 43]. The ScFv originated in light and heavy variable chains of a monoclonal antibody that diagnoses target antigens on tumor cells in an MHC-independent way. Antigen recognition elicits CAR-T cell cytotoxic function through dominating the signaling domains $[13,44,45]$.

CAR-T cell is clustered into four generations, composed of $\mathrm{ScFv}$ and $\mathrm{CD} 3 \zeta$ signaling domains. Additionally, there are the second and third generations that possess the one and two costimulatory molecules, respectively. T cell Redirected for Universal Cytokine Killing (TRUCK) is a fourth-generation CAR that is identified by secreting cytokines or biological factors in which their genes are inserted into TRUCK construction by transduction. Interestingly, it has been revealed that efficacy, cytotoxicity, proliferative capability, and persistence of the third generation of CAR-T cells have significantly been improved in comparison with the first generation (Fig. 1) $[12,46,47]$. The principle of CAR-T, its preparation, and four engineered generations of CAR-T cells have been shown in Figs. 2 and 3.

\section{CAR-T cell therapy in multiple myeloma}

Strikingly, the effectiveness of CAR-T cell therapy is well embraced for treating various hematological malignancies, mostly in acute and chronic leukemia, lymphoma, and multiple myeloma [40, 48]. Indisputably, CAR-T cell therapy would be considered one of the promising and powerful tools despite some important concerns about its efficacy and safety issues. CAR-T cells directed against CD19 are common types of CAR-T cells that have emerged for diverse hematological cancers, mostly leukemias and lymphomas [36, 37, 49, 50]. Furthermore, CAR-T cells targeting CD22 and CD20 have been investigated in ALL $[51,52]$ and relapsed/refractory NHL, respectively [53, 54]. Anti-CD22- and anti-CD20-CAR-T cell therapies have demonstrated a considerable antitumor efficacy. Also, CS-1, CD30, CD38, and CD138 are the other target antigens that can be targeted by CAR-T cells in different malignancies.

CAR-T cell therapy has also been improved to treat patients with multiple myeloma or other hematological malignancies. Previous findings implied that potential

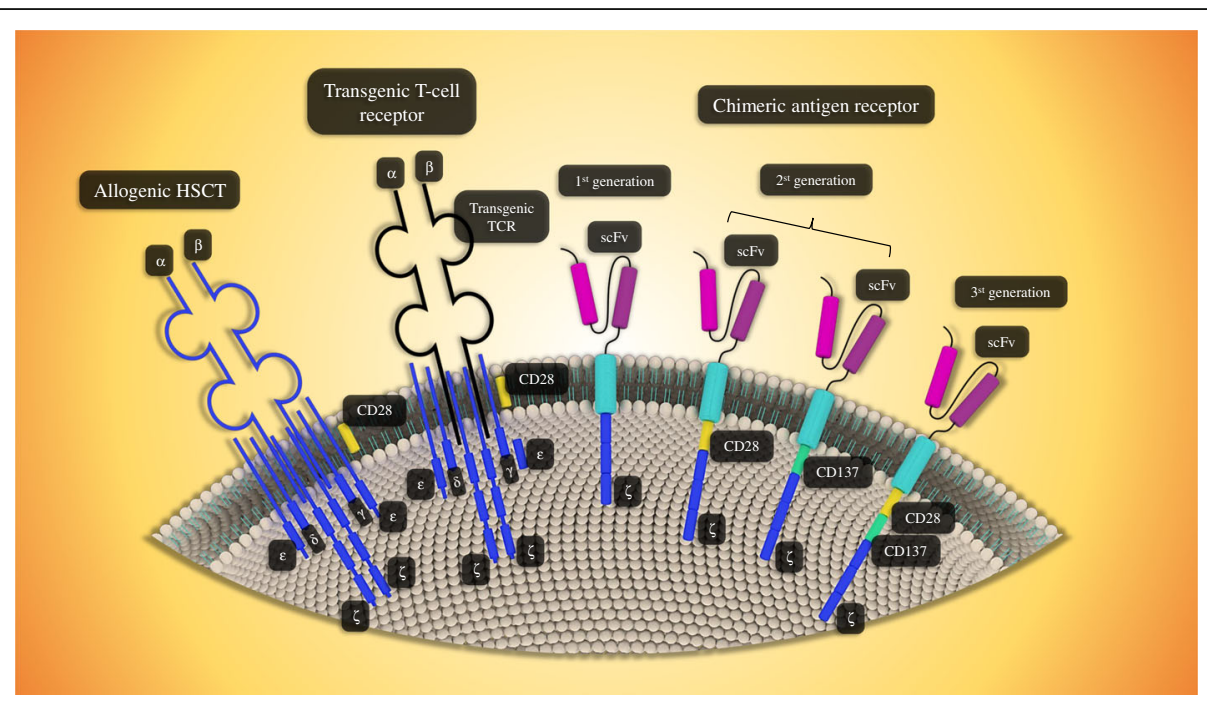

Fig. 1 Allogenic, transgenic, and chimeric antigen receptors. In this figure, every kind of receptor has been shown, however, chimeric antigen receptor has been made of three generations which are shown 


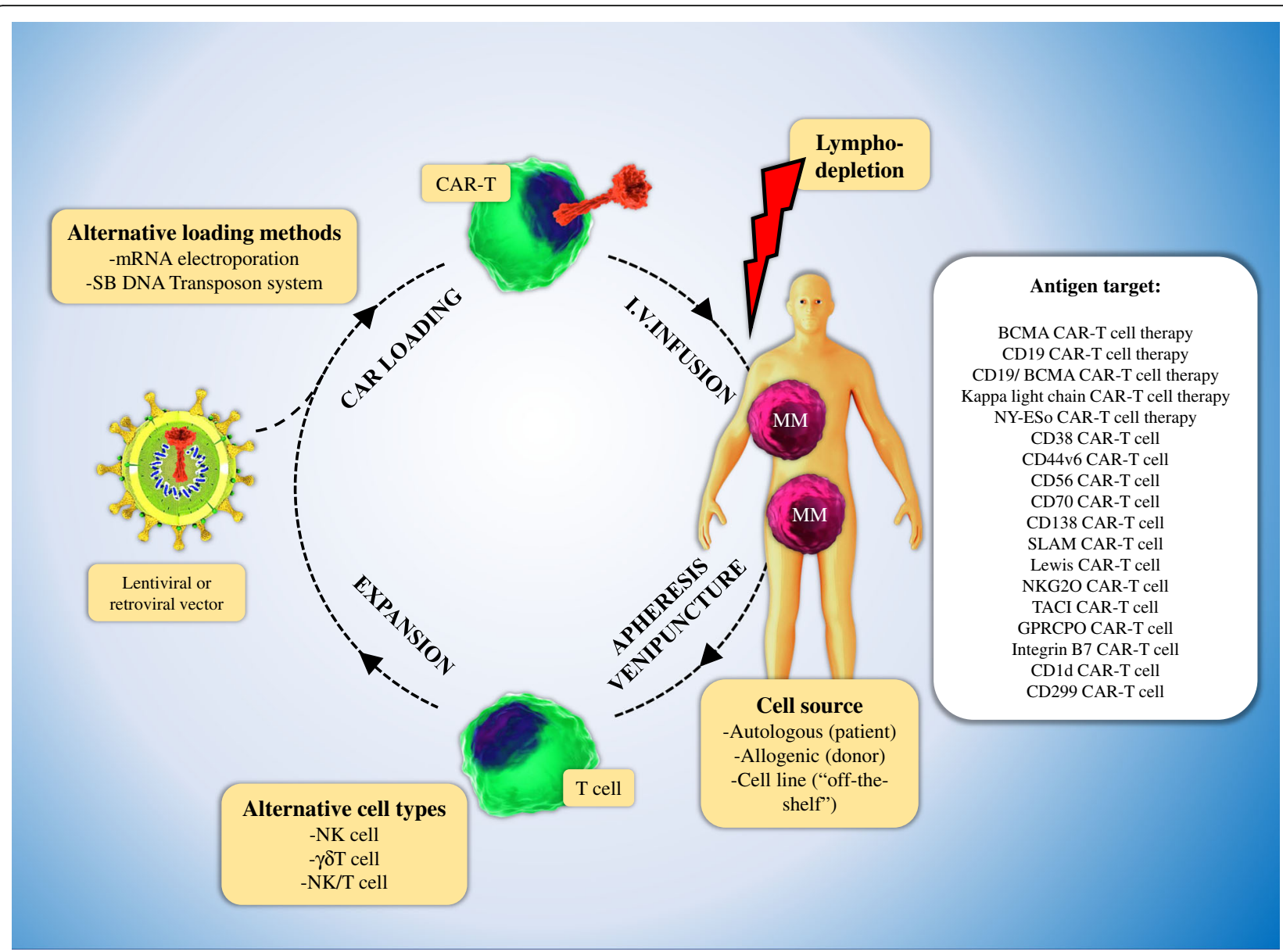

Fig. 2 Isolation, engineering, expansion, and administration of CAR-T cells in MM. CAR-T cells from patients with MM are usually produced from autologous T cells collected through leukapheresis (Stage 1). Allogeneic donor or cell lines can be used apart from the autologous T cells (11). $\gamma \delta$ T cells, NKT, and NK are applicable as alternative lymphocyte subsets to generate CAR-T cells. The next step performs in ex vivo which the cells are directed to be expanded (stage 2) and are loaded with a vector-encoding CAR gene (stage 3). Non-viral methods such as electroporation or sleeping-beauty can be done. IV injection of CAR-loaded T cells into the patients who usually receive chemotherapy before the lymphatic injection is the next step (step 4). Various MM antigens as CAR-T cells' targets have been shown

and appropriate antigens expressed on target cells can be contributed to procreate the specific CAR-T cells with high efficacy. Antigens that are associated with $\mathrm{MM}$ and can be targeted by CAR-T cells are included CD19, CD38, CD138, BCMA, Kappa (к) light chain, SLAM7, NKG2D, and GPRC5D. Here, we elaborate on overviewing the designed CAR-T cells against the mentioned antigens, and the efficacy of CAR-T Cell therapy in multiple myeloma (Fig. 4).

\section{BCMA CAR-T cell}

$B$ cell maturation antigen (BCMA) refers to a member of the tumor necrosis factor (TNF) family, specifically presented on B cells, normal and malignant plasma cells [55]. Principally, there is a close relationship between BCMA expression and several pivotal factors, comprising of transmembrane activator cyclophilin ligand interactor (TACI), calcium modulator, and B cell-activating factor of the TNF family (BAFF) receptor. BSMA argues the survival of B Cells at different development stages by exerting the BAFF, and proliferation-inducing ligand (APRIL) factors [56]. BCMA plays a substantial role in developing the multiple myeloma cells and considers a proper target antigen by anti-BCMA antibody-drug conjugate (GSK2857916), bispecific $\mathrm{T}$ cell engager (BiTE) (AMG420), and CAR-T cell therapy [57, 58]. Pieces of evidence have shown that BCMA has remarkable potential to be targeted by CAR-T cell with less on-target/offtumor toxicity, and antigen-dependent diminution in the expansion of CAR-T cells [59]. As a disadvantage, recognition of BCMA on MM cells by BCMA CAR-T cells would prevent through blocking role of soluble BCMA secreting by tumors into the blood circulation and peripheral tissues [60].

Up to now, several ongoing or completed studies have been implemented to investigate the various types of 


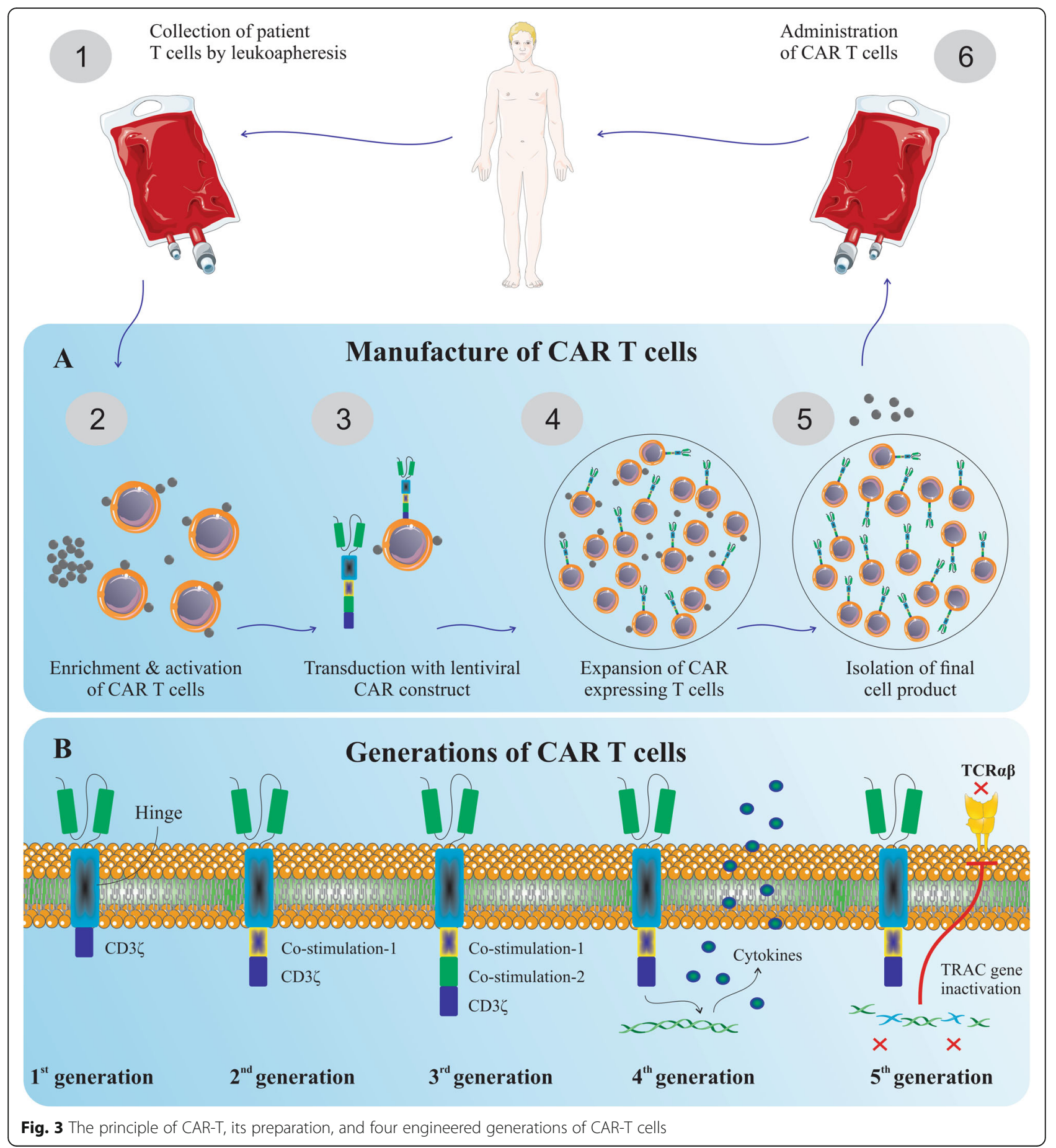

BCMA CAR-T cells against MM. The first clinical trial of BCMA-targeted CAR-T cell (NCT02215967) has been conducted by The National Cancer Institute, enrolling 24 patients with MM. The murine singlechain variable fragment $(\mathrm{ScFv}), \mathrm{CD} 3 \zeta$ (signaling domain), and $\mathrm{CD} 28$ (costimulatory domain) were the components of an anti-BCMA CAR-T cell. As a result, minor cytotoxicity was observed using the minimum dose of CAR-T cell $\left(0.3-3.0 \times 10^{6}\right.$ cells $\left./ \mathrm{kg}\right)$ along with a $20 \%$ overall response rate (ORR). In return, significant anti-tumor function with $81 \%$ ORR and severe cytokine release syndrome (CRS) were reported infusing the highest dose of CAR-T cell $(9 \times$ $10^{6}$ cells/kg) [61] (Table 1 ). 


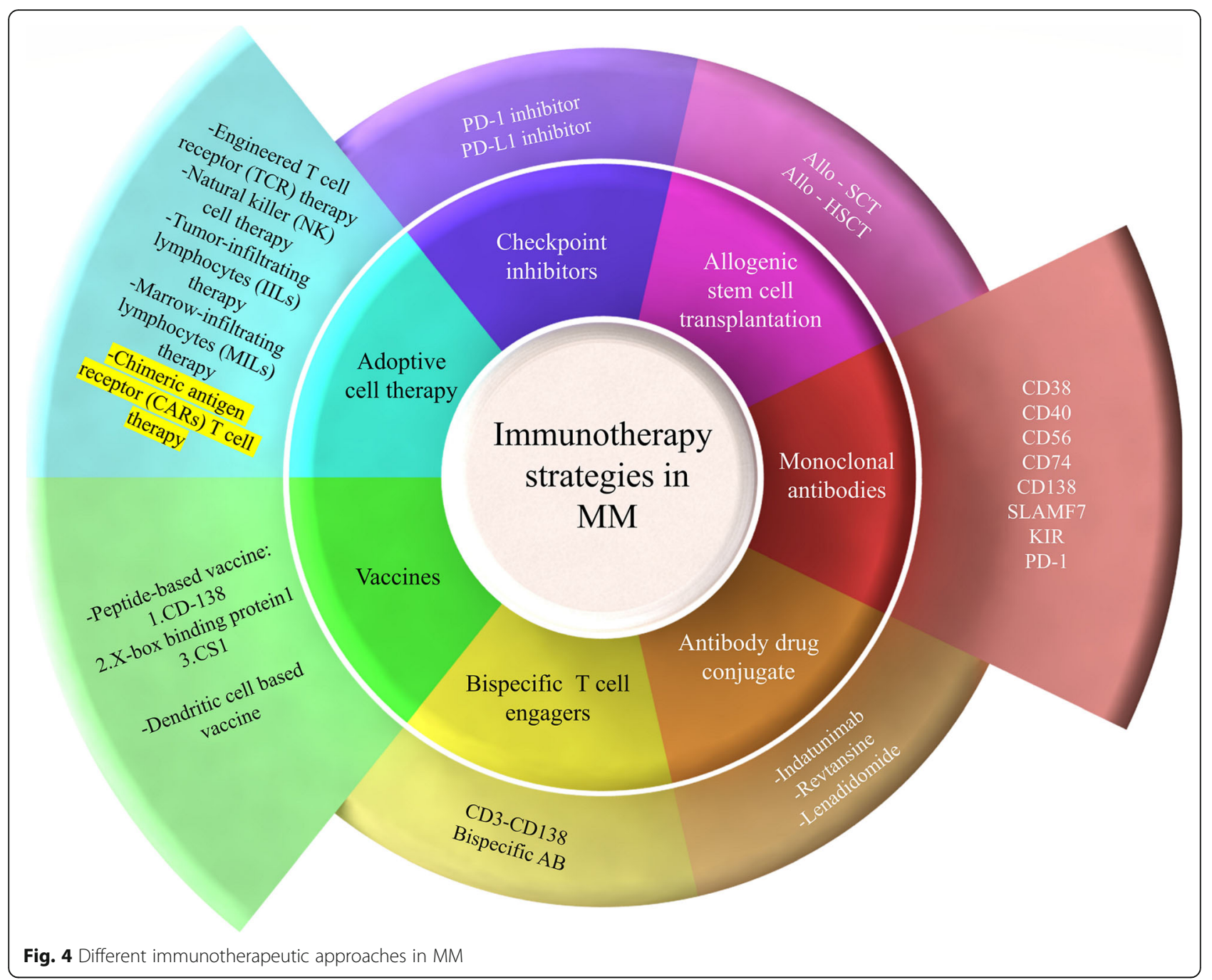

\section{bb2121 anti-BCMA CAR-T cell}

Another clinical study has examined the anti-BCMA CAR-T cell (bb2121) has been composed of anti-BCMA $\mathrm{ScFv}, \mathrm{CD} 3$, and 4-1BB domains in 33 RRMM patients (NCT02658929). Eighty-five percent ORR was reported among 12 patients, while side effects showed 76\% CRS and $42 \%$ neurotoxicity $[62,63]$.

\section{bb21217 anti-BCMA CAR-T cell}

The bb21217 anti-BCMA CAR-T cell is another nextgeneration CAR that is evaluated in MM patients. A phase I dose-escalation clinical study on bb21217 (NCT03274219) showed that 7 RRMM patients who were treated with $150 \times 10^{6} \mathrm{CAR}-\mathrm{T}$ cells had a significant expansion of CAR-T cells, five of which diagnosed with grade 1-3 [64].

\section{LCAR-B38M anti-BCMA CAR-T cell}

Bispecific CAR-T cell (LCAR-B38M) has been devised to target $\mathrm{VHH} 1$ and $\mathrm{VHH} 2$ epitopes of BCMA and investigated in advanced RRMMs by a multicenter study (NCT03090659). Although findings have revealed 88\% ORR and $68 \%$ complete responses (CR) in patients who were treated with LCAR-B38M anti-BCMA CAR-T cells, some adverse effects, including CRS, leukopenia, thrombocytopenia, and pyrexia, have been reported [65].

\section{P-BCMA-101 anti-BCMA CAR-T cell}

P-BCMA-101 is identified as a novel product of CAR-T cell containing fully humanized anti-BCMA ScFv extracellular domain, $\mathrm{CD} 3 \zeta$, and $4-1 \mathrm{BB}$ signaling domains. The structure of CAR- $T$ cell shows more potent and has a high level of expression along with less immunogenicity which is provided by applying a transposon system instead of viral vectors. In a phase I clinical trial study (NCT03288493), the efficacy and safety of P-BCMA-101 CAR-T cells were assessed in patients with RRMM in which approximately one of twelve patients indicated $\mathrm{CR}$, and one of them was diagnosed with grade $2 \mathrm{CRS}$ $[66,67]$. 
Table 1 BCMA-targeted CAR T cell clinical trials in multiple myeloma

\begin{tabular}{|c|c|c|c|c|c|c|c|c|c|}
\hline \multirow{2}{*}{$\begin{array}{l}\text { Signal } \\
\text { domain }\end{array}$} & \multirow[t]{2}{*}{ ORR } & \multicolumn{4}{|c|}{ Efficacy } & \multicolumn{2}{|l|}{ Side effect } & \multirow[t]{2}{*}{ Conditioning } & \multirow[t]{2}{*}{ Registration code } \\
\hline & & $\overline{C R}$ & sCR & PR & $\overline{\text { VGPR }}$ & $\overline{\text { CRS }}$ & CRES & & \\
\hline CD28 & $20 \%$ & - & - & 1 & 1 & Gr3/4, 38\% (high dose) & Gr3/4, 19\% (high dose) & CP/Flu & NCT02215967 \\
\hline CD28 & $87 \%$ & - & - & - & - & Gr3, $14 \%$ & - & CP/Flu & ChiCTR-OPC-16009113 \\
\hline $4-1 \mathrm{BB}$ & $85 \%$ & 3 & 12 & 4 & 9 & Gr1/2, 70\% & $\begin{array}{l}\text { Gr1/2, 39\% } \\
\text { Gr4, 3\% }\end{array}$ & CP/Flu & NCT02658929 \\
\hline $4-1 \mathrm{BB}$ & $86 \%$ & - & 1 & 2 & 3 & $\begin{array}{l}\mathrm{Gr} 1 / 2,50 \% \\
\mathrm{Gr} 3,12.5 \%\end{array}$ & Gr4, $12.5 \%$ & $\mathrm{CP}$ & NCT03274219 \\
\hline $4-1 \mathrm{BB}$ & $88 \%$ & 39 & - & 8 & 3 & $\begin{array}{l}\mathrm{Gr} 1 / 2,83 \% \\
\mathrm{Gr} 3 / 4,7 \%\end{array}$ & Gr1, $1.8 \%$ & $\mathrm{CP} / \mathrm{Flu}$ & NCT03090659 \\
\hline $4-1 \mathrm{BB}$ & $88.2 \%$ & - & 13 & - & 2 & $\begin{array}{l}\text { Mild, } 10 \\
\text { Severe, } 6 \\
\text { Very severe, } 1\end{array}$ & - & CP/Flu & ChiCTR-ONH-17012285 \\
\hline $4-1 \mathrm{BB}$ & $89 \%$ & 1 & 1 & 5 & 1 & $\mathrm{Gr} 2,1$ & - & CP/Flu & NCT03288493 \\
\hline $4-1 \mathrm{BB}$ & $100 \%$ & 1 & 2 & 1 & 2 & Gr1/2, 75\% & $\mathrm{Gr} 1 / 2,38 \%$ & CP/Flu & NCT03430011 \\
\hline $4-1 \mathrm{BB}$ & $100 \%$ & 3 & - & 4 & 6 & Gr1-3, 1 & none & CP/Flu & NCT03915184 \\
\hline $4-1 \mathrm{BB}$ & $64 \%$ & - & - & - & - & $\begin{array}{l}\mathrm{Gr} 1 / 2,40 \% \\
\mathrm{Gr} 3,20 \%\end{array}$ & Gr2, $10 \%$ & CP/Flu & NCT03070327 \\
\hline $4-1 \mathrm{BB}$ & $100 \%$ & 4 & - & 4 & 1 & $\begin{array}{l}\text { Mild } \\
\text { DLT }\end{array}$ & - & $\mathrm{CP} / \mathrm{Flu}$ & ChiCTR1800018137 \\
\hline $4-1 \mathrm{BB}$ & $79 \%$ & 3 & 4 & - & 2 & Mild & - & CP/Flu & NCT03093168 \\
\hline $4-1 \mathrm{BB}$ & $48 \%$ & 1 & 1 & 5 & 5 & $\mathrm{Gr} 3 / 4,32 \%$ & $\mathrm{Gr} 3 / 4,12 \%$ & $\mathrm{CP}$ or none & NCT02546167 \\
\hline $4-1 \mathrm{BB}$ & $100 \%$ & 1 & - & 3 & - & Under Gr3 & - & CP/Flu & NCT03661554 \\
\hline $4-1 B B$ & $95 \%$ & 3 & 9 & 3 & 5 & $\begin{array}{l}\text { Gr1-2, 86\% } \\
\text { Gr3, 5\% }\end{array}$ & - & CP/Flu & ChiCTR-OIC-17011272 \\
\hline OX40, CD28 & $80 \%$ & - & 1 & 2 & 1 & Mild & - & $\mathrm{Bu}-\mathrm{CP}+\mathrm{ASCT}$ & NCT03196414 \\
\hline OX40, CD28 & $100 \%$ & 3 & - & - & 6 & Mild & - & CP/Flu & NCT03455972 \\
\hline
\end{tabular}

$B C M A$ B cell maturation antigen, $C A R$ chimeric antigen receptor, $O R R$ overall response rate, $C R$ complete response, $s C R$ stringent complete response, $P R$ partial response, VGPR very good partial response, $C R S$ cytokine release syndrome, $C R E S$ cell related encephalopathy syndrome, $G r$ grade, $D L T$ dose-limiting toxicity, $C P$ cyclophosphamide, Flu fludarabine, Bu busulphan, ASCT autologous stem cell transplantation

\section{MCARH171 anti-BCMA CAR-T cell}

Another next-generation anti-BCMA CAR-T cell called MCARH171 has been investigated in patients with RRMM in a phase I dose-escalation trial (NCT03070327) study. This type of CAR-T cell has consisted of a humanized anti-BCMA ScFv, CD3 , 4-1BB, and a truncated epidermal growth factor. Four doses of CAR-T cells $\left(72 \times 10^{6}, 137 \times 106,475 \times 10^{6}\right.$, and $818 \times$ $10^{6}$ ) were administrated to patients, resulting in approximately $64 \%$ ORR. As an adverse impact, up to $40 \%$ of patients were diagnosed with 1-3 grade CRS [68].

\section{BRD015 anti-BCMA CAR-T cell}

A phase I clinical trial study (ChiCTR-OPC-16009113) examined the proficiency of BRD015 anti-BCMA CAR$\mathrm{T}$ cells in 28 RRMM cases. BRD015 has been composed

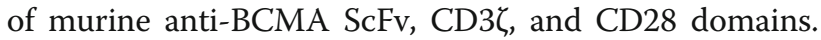
It was administrated with 5.4-25.0 × $10^{6} \mathrm{CAR}-\mathrm{T}$ cells $/ \mathrm{kg}$ dose. Encouragingly, in patients expressing the high level of BCMA on MM cells, $87 \%$ ORR and $73 \%$ CR were reported. Moreover, 100\% ORR and 33\% CR were detected in patients expressing a low level of BCMA on tumor cells [69].

\section{CT103A anti-BCMA CAR-T cell}

In another phase I trial study (ChiCTR1800018137), CT103A BCMA-targeted CAR-T cell, another nextgeneration CAR-T cell, was evaluated in nine patients diagnosed with MM. One to $6 \times 106$ cells/kg CAR-T cells were administered, resulting in $100 \%$ ORR and $67 \%$ CR [70].

\section{CD19-CAR-T cell}

CD19 alludes to a signaling factor of a multimolecular complex on mature B cell and is also implied as a member of the immunoglobulin superfamily. It is considered an important and common target antigen-expressing on diverse $\mathrm{B}$ cell hematological malignancies, such as acute and chronic leukemias, and lymphomas [71]. As a result, since CD19 has an insignificant expression on MM cells, it is not a good choice for applying in MM patients. However, there is an apparent relationship between drug 
resistance related to $\mathrm{BM}$ microenvironment and $\mathrm{CD} 19$ expression in MM. Furthermore, CD19 expression has been evidenced on multiple myeloma stem cells (MMSCs), a population of MM tumors possessing the self-renewal and drug resistance capabilities [72, 73]. Thus, CD19 can be contemplated as a reliable target antigen for MM treatment strategy. It has been reported that following the administration of melphalan (highdose) and autologous stem cell transplantation (ASCT), anti-CD19-CAR-T cell (CTL019) has emerged welltolerated complete response in refractory MM cases [35]. Thus, CD19 can be considered a promise target antigen for MM treatment. Accordingly, a clinical trial study (NCT02135406) was conducted to evaluate the CTL019 therapy in 10 patients after ASCT and a high dose of melphalan. Concisely, the combinatorial treatment of ASCT and CTL019 led to a marked elevation of the progression-free survival (PFS) rates in MM patients with advanced stage [74] (Table 2).

\section{CD19/BCMA CAR-T cell}

In a clinical trial examination (NCT03196414) [75], Fu et al. administrated a third-generation CAR-T cell using anti-BCMA and anti-CD19 ScFv as an extracellular portion, and $\mathrm{CD} 3 \zeta$ signaling domain accompanied by $\mathrm{CD} 28$ and OX40 costimulatory molecules in eight RRMM patients. Firstly, patients were treated with $1 \times 107 / \mathrm{kg}$ CD19-CAR-T cells, and subsequently, they received $40 \%$ of BCMA CAR-T cells and $60 \%$ of the remaining cells on the next day. Similarly, in another study (SZ-MMCART02 study, NCT 03455972) [76], Fu et al. administered the abovementioned CAR-T cells following the autologous transplantation as described above. The results showed approximately $100 \%$ ORR from the nine patients after treating with CAR-T cells.
Furthermore, in a phase II clinical trial study (ChiCTR-OIC-17011272) [77], twenty RRMM patients were treated by both humanized anti-CD19 CAR-T cells $(1 \times 106$ cells $/ \mathrm{kg})$ and murine anti-BCMA CAR-T cells $(1 \times 106$ cells $/ \mathrm{kg})$, resulting in $95 \%$ ORR.

\section{Kappa (к) light chain-CAR-T cell}

The light chain subsets ( $\kappa$ or $\lambda$ ) can be expressed on mature B cells and targeted by immunotherapy-based strategies. Therefore, in MM patients, a specified subset of the light chain can be targeted on MM tumor cells which would be different on healthy B cells. Immunoglobulins are not typically manifested on the plasma cell surface; howbeit, there is likely expression of immunoglobulins on MM stem cells [78]. In phase I of the clinical trial study, a light chain anti-kappa free monoclonal antibody, so-called MDX-1097, was assessed in patients with MM. Encouragingly, in one patient, a lower level of the serum-free light chain (FLC) was demonstrated, and also a complete metabolic reaction in another one was reported after the treatment. Also, 6 months period of stable disease (SD) was documented by phase II of the multiple-dose trial study in ten MM patients [79].

The light chain on MM cells can be remarkably targeted by CAR-T cells. Additionally, B cell depletion in different treatments of candidate patients will be led to the hard selection of a specific light chain for CAR-T cell therapy. In a phase I clinical trial study (NCT00881920) conducted by Ramos et al. [80], к-CAR$\mathrm{T}$ cell was engineered for recognizing the $\mathrm{K}$-light chain on tumor cells in seven MM and nine non-Hodgkin lymphoma patients. Before CAR-T cell therapy, patients treated with chemotherapy drugs were found to have no significant response against these drugs. After CAR-T cell therapy, 17 months of stable minimal residual

Table 2 Non-BCMA-targeted CAR T cell clinical trials in multiple myeloma

\begin{tabular}{|c|c|c|c|c|c|}
\hline $\begin{array}{l}\text { Target } \\
\text { antigen }\end{array}$ & $\begin{array}{l}\text { Signaling } \\
\text { domain }\end{array}$ & Clinical responses & Side effects & Conditioning & $\begin{array}{l}\text { Registration } \\
\text { code }\end{array}$ \\
\hline CD19 & $4-1 \mathrm{BB}$ & $\begin{array}{l}\text { ORR, 20\% } \\
\text { CR, } 1 \\
\text { VGPR, } 6 \\
\text { PR,2 }\end{array}$ & $\begin{array}{l}\text { Mild CRS Hypogammaglobulinemia } \\
\text { Autologous GvHD }\end{array}$ & $\mathrm{HDM}+\mathrm{ASCT}$ & NCT02135406 \\
\hline \multirow[t]{3}{*}{ CD138 } & CD28 & $4 \mathrm{SD}$ & Mild CRS & $\begin{array}{l}P C D, C P \text {, or } \\
V A D\end{array}$ & NCT01886976 \\
\hline & $4-1 \mathrm{BB}$ & $\begin{array}{l}\mathrm{SD}>3 \mathrm{~m}, 4 \\
\text { Circulating PCL cells, } \\
1\end{array}$ & $\begin{array}{l}\text { Infusion-related fever nausea and vomiting possible } \\
\text { TLS }\end{array}$ & CP/Flu & $?$ \\
\hline & ND & $\mathrm{PR}, 1$ & CRS grade 2 & $\begin{array}{l}P C D, C P \text { or } \\
\text { VAD }\end{array}$ & $?$ \\
\hline Kappa LC & CD28 & SD, 4 & Mild CRS lymphopenia grade 3 & $\mathrm{CP}$ or none & NCT00881920 \\
\hline NKG2DL & Dap10 & ORR, $0 \%$ & Mild CRS & None & NCT02203825 \\
\hline
\end{tabular}

$B C M A$ B cell maturation antigen, $C A R$ chimeric antigen receptor, $O R R$ overall response rate, $C R$ complete response, $P R$ partial response, $V G P R$ very good partial response, $S D$ stable disease, $C R S$ cytokine release syndrome, $H D M$ high-dose melphalan, $A S C T$ autologous stem cell transplantation, $P C D$ pomalidomidecyclophosphamide-dexamethasone, CP cyclophosphamide, VAD vincristine-doxorubicin-dexamethasone, Flu fludarabine, GvHD graft-vs.-host disease, $T L S$ tumor lysis syndrome, ND no data, NKG2D natural killer group 2-member D 
disease, 2 years SD, and transient SD were reported among the MM patients; however, three patients indicated no objective responses to CAR-T cell therapy. Interestingly, severe CRS or other adverse effects were not demonstrated in patients following CAR-T cell therapy.

\section{NY-ESO-1-CAR-T cell}

New York Esophageal Squamous Cell Carcinoma 1 (NYESO-1) refers to an intracellular oncoprotein that belongs to the cancer/testis (CT) antigens family. Also, NY-ESO-1 expresses in various cancers, like relapsed MM. In this regard, TCR-mimetic CAR-T cells have been engineered to target the Y-ESO1/HLA peptide complex [81, 82].

In a preclinical study, engineered NY-ESO-1-CART cells were administered to a mouse model with the NYESO-1/HLA-A2 MM, and evaluations revealed inhibitory effects on tumor cells. Interestingly, coadministrating the engineered $\mathrm{T}$ cells expressing NYESO1 and membrane-bound IL-15 could robust the anti-tumor cytotoxicity and persistence of memory CAR-T cells [81].

In a study conducted by Schuberth et al., anti-NYESO-1 CAR T cell was designed to distinguish the HLAA*0201-NY-ESO-1157-165. Furthermore, MM cells that endogenously expressed NY-ESO-1 antigen were targeted by engineered CAR-T cells, redirecting to tumor targets. Through the anti-tumor cytotoxicity impact, CAR-T cells led to lysing the MM cells and secreting IFN $\gamma$. In addition to the effector role of $\mathrm{T}$ cells, NYESO-1 induced the generation of memory phenotype of $\mathrm{T}$ cells and IFNY secretion [82]. In a phase I/II of the trial study, anti-NY-ESO-1 CAR-T cell efficacy was assessed after an autologous stem cell transplantation in twenty advanced MM cases. Findings revealed that about $80 \%$ of the patients showed appropriate clinical responses with 19.1 months median PFS [83].

\section{CD38-CAR-T cell}

CD38 is a target antigen on MM cells known as a transmembrane glycoprotein which has several pivotal roles, including calcium regulation, signal transduction, and cell adhesion processes. Its expression is generally evidenced on NK cells, T cells, B cells, myeloid precursors, and plasma cells. Also, different healthy tissues have been shown to express comprising of osteoclast, guts, nervous system, prostate cells, and muscle cells [5, 84]. CD38 is intermediately expressed on both myeloma cells and healthy hematopoietic cells which elevates the risk of on-target/off-tumor toxicity [85]. Among the immunotherapy-based approaches, various mAbs have been developed to target CD38 on MM cells. Firstly, human anti-CD38 monoclonal named Daratumumab obtained FDA approval for treating RRMM alone or combinatorial with other medications. To eliminate the tumor cells, Daratumumab prompts the antibodydependent phagocytosis, antibody-dependent $\mathrm{T}$ cellmediated cytotoxicity (ADCC), and complementdependent cytotoxicity (CDC) phenomena [86]. Moreover, isatuximab (SAR650984) is identified as another anti-CD38 mAb with potential anti-tumor cytotoxicity against MM [87].

According to the varying influences of mAbs on MM, there is a possibility to generate the anti-CD38 CAR-T cell. Previous studies have emerged that the anti-CD38CAR T cells led to lyse the $\mathrm{CD} 38^{+} \mathrm{MM}$ cells with the capability of proliferation and cytokine production. Although using the anti-CD38-CAR-T cell has been shown to affect $\mathrm{CD} 38^{+} \mathrm{MM}$ cells, an undesirable on-target/offtumor toxicity on $\mathrm{CD} 8^{+}$healthy hematopoietic cells and healthy tissues was reported. To prevent this toxicity, the light chain exchange strategy can be applied to generate the lower affinity $\mathrm{ScFv}$. In this regard, it accurately targets only MM cells expressing a high level of CD38 without affecting normal cells with low CD38 expression [88]. Also, CD38 nanobody-based CAR-T cells are being generated and investigated in patients with MM. As a result, CAR-T cells demonstrated the effective anti-tumor function with slight on-target/off-tumor toxicity [89].

Moreover, caspase-9-based suicide genes can be used to solve this adverse effect of CAR-T cell [85]. As alternative approaches, using the all-trans retinoic acid or the histone deacetylase inhibitor panobinostat could selectively upregulate the expression of CD38 on MM tumor cells that might augment CAR-T cell cytotoxicity, and diminish the toxicity on healthy cells $[90,91]$.

To treat RRMM patients, anti-CD38-CAR-T cell monotherapy (NCT03464916) and combinational therapy targeting other molecules, including BCMA (NCT03767751), CD19 (NCT03125577), BCMA and NY-ESO-1 (NCT03638206), and BCMA plus CD138 or CD56 (NCT03473496, NCT03271632) have been investigated in several clinical trial studies.

\section{CD44v6-CAR-T cell}

CD44 isoform variant $6(\mathrm{CD} 44 \mathrm{v} 6)$ glycoprotein is the main hyaluronan receptor that is commonly overexpressed on hematologic and epithelial tumors, evidenced in $43 \%$ of MM patients mostly in advanced and highrisk cases [92]. CD44v6 is a proper candidate for targeting by mAbs. In a phase I of the radioimmunotherapy trial study, bivatuzumab mertansine as a humanized anti-CD44v6 $\mathrm{mAb}$ indicated a protected consequence with merely reversible reactions in the skin [93]. In a study, Casucci et al. [94] have engineered the CD44v6CAR-T cell to target tumor cells in patients with acute 
myeloid leukemia (ALL) and MM. The CD44v6-CAR-T cell that aimed to secrete IL-7 and IL-15 cytokines illustrated the greater anti-tumor function against MM cells with no toxic effects on normal keratinocytes and hematopoietic stem cells. Although reversible monocytopenia was reported as a main detrimental effect of CD44v6-CAR-T cell, it can be helpful to impede the CRS occurrence. For instance, suicide genes, including thymidine kinase gene and inducible caspase 9 gene, as safety switches can be administered to decrease CAR-T cell toxicity.

Moreover, a multicenter phase I/II of a clinical trial has been conducted by the EURE-CART project to investigate the CD44v6-CAR- $\mathrm{T}$ cell in acute myeloid leukemia (ALL) and MM patients [95] (see more details in https://www.eure-cart.eu/).

\section{CD56-CAR-T cell}

CD56 belongs to the immunoglobulin superfamily and is identified as a cell surface glycoprotein with regulatory roles in cell-cell and cell-matrix interplay. CD56 is generally expressed on healthy activated T cells, NK cells, epithelial cells, and neural cells, but not on normal plasma cells. Furthermore, CD56 overexpression on tumoral plasma cells has been documented in over $78 \%$ of MM patients $[2,96]$. Anti-CD56 monoclonal antibodies have been created to target $\mathrm{CD} 56^{+} \mathrm{MM}$ cells. For example, a humanized mAb called HuN901 demonstrated effective anti-tumor cytotoxicity in vitro and in vivo studies [97]. In a dose-escalation phase I trial study, lorvotuzumab mertansine (LM) that is considered an antibody-drug conjugate, has been evaluated against $\mathrm{CD} 6^{+}$tumor cells in 37 relapsed MM cases. Outcomes revealed the potent and well-tolerated anti-myeloma cytotoxicity impacts of LM solely, or along with lenalidomide and dexamethasone medications [98, 99]. However, there is the possibility of infection risks and infection-related deaths in using the LM, for it elicits the depletion of $\mathrm{CD}^{+} 6^{+}$immune effector cells [100]. In a preclinical study, Benjamin et al. [101] have designed the anti-CD56 CAR-T cell to target MM cells. Furthermore, CAR-T cell therapy has been investigated in clinical trial studies against CD56 in combination with other antigens that expressing on MM cells (NCT03473496 and NCT03271632). Since CD56 is expressed in central and peripheral nervous systems, neurologic toxicity may be considered a concern of using CD56-CAR-T cells.

\section{CD70-CAR-T cell}

CD70 (CD27L) belongs to the tumor necrosis factor family that has a vital role in plasma cell differentiation. CD70 overexpression has been seen in solid tumors and hematological malignancies in comparison with a low expression on healthy cells [102]. CD70 is a potential target for mAb therapy. A humanized anti-CD70 mAb named CSGN-70 has been generated against MM cells based on anti-tumor cytotoxicity, and Fc-dependent antibody activity [102]. BMS-936561 and SGN-75 mAbs are the other examples of mAbs that have been produced to attack myeloma cells in MM cases [103, 104]. In a preclinical study, findings indicated that anti-CD70 CAR T cells could target the $C D 70^{+} \mathrm{MM}$ cells with high efficacy and safety [105]. According to previously published data, the anti-CD70 CAR-T cell demonstrated potent functionality in both animal and human cancers in vitro $[106,107]$. In a study performed by Shaffer et al. [108], an anti-CD70 CAR-T cell was engineered using the $\mathrm{ScFv}$ originated from CD27. Consequently, effective eradication of $\mathrm{CD}^{+} 0^{+} \mathrm{MM}$ cells and remarkable persistence of $\mathrm{T}$ cells were reported after CAR-T cell therapy. Despite the therapeutic application of anti-CD70 CAR T cells, it is not broadly utilized in MM patients. Thus, the expression of CD70 on MM cells appeared to be less and has variable grades [109].

\section{CD138-CAR-T cell}

CD138 that called syndecan 1 is an adhesion molecule belonging to the syndecan family of heparan sulfate proteoglycans. It has a vital role in cell proliferation and the molecular adhesin process through binding to the collagen and fibronectin (extracellular matrix (ECM) molecules) $[110,111]$. It can also bind to survival factors [112], such as cell proliferation-inducing growth factors and a proliferation-inducing ligand (APRIL) $[112,113]$. Generally, mature epithelial and several malignant plasmas, as well as normal cells, could express CD138; however, it is not expressed on normal $\mathrm{T}$ and $\mathrm{B}$ cells [114]. Also, CD138 is overexpressed on MM cells, mostly in relapse or progressive disease that can lead to cancer progression [115]. Therefore, CD138 can be considered a potential and attractive candidate to target in MM patients. An anti-CD138 antibody-drug conjugate named BT062 (indatuximab) was applied as a therapeutic agent in MM patients. BT062 was tested in phase I/II of a clinical trial study, resulting in an objective clinical response in 1 patient out of 23 patients [116]. Similarly, the combination of BT062 with lenalidomide enhanced the overall response rate to approximately $83 \%$ [117].

Based on the accomplished preclinical examination, anti-CD-138 CAR-T cell therapy has been demonstrated a significant anti-tumor toxicity influence against myeloma cells in vitro and in vivo studies [118]. In a clinical trial study (NCT01886976), CD138-CAR-T cell therapeutic effect was evaluated in five RRMM patients following chemotherapy and stem cell transplantation. According to the findings, 3 to 7 months of SD, and a $10.5 \%$ to $<3 \%$ decrease in the number of MM cells were 
reported in four patients out of five patients who were administered with an average dose of $0.756 \times 107$ CAR$\mathrm{T}$ cells/kg. Also, an increased frequency of CAR-T cells was identified after the first 2 months in the bone marrow [119].

Since the skin and mucosal toxicities were evidenced as adverse effects of CD138-CAR-T cells due to the broad expression of CD138 on normal epithelial cells, caution should be exercised in its application. Nonetheless, the safety of CD138-CAR-T cells and less toxicity on epithelial cells were found by a preclinical investigation [120].

Also, targeting CD138 by immune cells will confront problems due to the CD138 shedding from MM cells, and escaping from the immune system. This suggests using CD138-CAR-T cell in combination with CAR-T cell against other target antigens on the surface of the MM cells [121]. Consequently, different clinical studies have been planning to investigate the CD138-CAR-T cell therapy in combination with other CAR-T cells (NCT03196414, NCT03473496, and NCT03271632).

\section{SLAM7-CAR-T cell}

SLAMF7 is a transmembrane receptor called CD319 or CS1 which belongs to the lymphocytic signaling activation molecule family [122, 123]. SLAMF7 contributes to phagocytosis of different hematopoietic malignant cells by macrophages [124]. Usually, SLAMF7 is expressed on a broad range of immune cells, including CD4 and CD8 T cells, NK cells, activated B cells, plasma cells, dendritic cells, and monocytes. SLAMF7 was first recognized as an NK cell receptor [125-127]. Also, SLAMF7 is a prevalent antigen is targeted by CAR-T cells. SLAMF7 has been shown to express remarkably on malignant plasma cells without expressing on hematopoietic stem cells and nonhematologic tissues. Generally, SLAM7 is also expressed in premalignant and new patients diagnosed with MM [126, 128]. Anti-SLAMF7 therapeutic antibodies have been developed, like humanized Elotuzumab mAb which obtained FDA approval to treat MM cases in combination with lenalidomide and dexamethasone medications [129]. In multiple clinical trial studies, anti-SLAMF7 CAR-T cells were investigated against myeloma cells. Anti-SLAMF7 CAR-T cells have engineered using the $\mathrm{ScFv}$ that derived from elotuzumab fused to the healthy donor and MM patients' $\mathrm{T}$ cells. It has been reported that anti-SLAMF7 CAR-T cells could eliminate the primary and MM tumor cell lines, as well as normal lymphocytes with significant expression of SLAMF7 [125, 130]. In a clinical trial study (NCT03710421), SLAMF7-CAR-T cell containing the anti-SLAMF7 ScFv, memory-enriched T cells, and truncated EGFR (EGFRt) molecule was generated against MM cells. In this regard, It was observed that severe immune-mediated adverse events following administration of CAR $\mathrm{T}$ cells can be attenuated by cetuximab (EGFR monoclonal antibody) by inducing the suicide of CAR-T cell in an antibody-based-safety-switch manner [131].

UCARTCS1 is an example of an anti-SLAMF7 CAR-T cell that was designed for MM using the healthyallogeneic $\mathrm{T}$ cell, and transcription activator-like effector nuclease (TALEN)-targeted gene editing. TALEN strategy shows a transient expression of endogenous, and restriction of SLAMF7-originated CAR-T cell fratricide. Based on the in vitro analysis, potent anti-tumor activity and MM cell lysis were reported using the UCARTCS $[130,132]$. Other studies have determined the efficacy of either anti-SLAMF7 CAR-T cell or its dual form (SLAM F7/BCMA CAR) [124] along with its combination with other anti-MM drugs, such as daratumumab and lenalidomide $[54,133]$.

\section{Lewis Y-CAR-T cell}

The carbohydrate antigen Lewis Y (LeY) alludes to a target antigen overexpressing around 50\% of MM that correlated with the Lewis blood group antigen system. Interestingly, the lower expression level of the LeY on healthy cells makes it a suitable candidate for MM treatment [134]. According to previously published preclinical studies, LeY-CAR-T cells indicated a potential antitumor activity without on-target/off-tumor toxicity problem [135]. Moreover, anti-LeY CAR-T cell is underway the investigation in phase I of the clinical trial study (NCT01716364) which has not been reported in any results yet.

\section{NKG2D-CAR-T cell}

Natural killer group 2-member D (NKG2D) is a transmembrane protein which has an activating role on cell surface receptor. Generally, NKG2D expresses on several known effector CD8 T cells, comprising of $\gamma \delta \mathrm{T}$ cells, NKT cells, and NK cells [136]. NKG2D detects multiple ligands, such as UL16-binding proteins (ULBP) and major histocompatibility complex class I polypeptiderelated sequence (MIC) A/B. In response to infections, DNA damage, malignant transformations, and mentioned ligands will overexpress in tissues while the ligands are absent in physiological states. NKG2D expression has been reported in several solid and hematological cancers, such as AML and MM [137, 138]. Thus, NKG2D can be considered a potential target antigen for CAR-T cell therapy against MM. In a preclinical study conducted by Leivas et al. [139], NKG2DCAR-NK cells demonstrated a potent eradication of tumor cells along with remarkable suppression of tumor growth; however, no effective responses were detected using NKG2D CAR-transduced T cells. 
In the first human phase I clinical study, Baumeister et al. [140] have engineered the NKG2D-CAR-T cell to target several specific NKG2D ligands. The efficacy and safety of first-generation NKG2D-CAR-T cells were assessed in progressive RRMM and acute myeloid leukemia/myelodysplastic syndrome. Outcomes of the abovementioned study have implied that there was no prolonged persistence of CAR-T cell, objective clinical response, CRS, and neurotoxicity. Lymphodepletion is an essential step before CAR-T cell therapy is required to increase CAR-T cell engraftment [141, 142]. Accordingly, failure of this treatment in the mentioned trial study may be due to the use of first-generation CAR-T cell with limited cytotoxicity, and performing no lymphodepleting chemotherapy before CAR-T cell therapy.

\section{TACI-CAR-T cell}

Transmembrane Activator and CAML Interactor (TACI) belong to the tumor necrosis factor receptor superfamily that is generally expressed at a lower level on malignant plasma cells [143]. TACI bounds to its ligand named APRIL which will be mediated by CD138 as a coreceptor [144]. APRIL is a common ligand for TACI and BCMA. In a preclinical study, Lee et al. [143] demonstrated that both $\mathrm{BCMA}^{+} \mathrm{TACI}^{+}$and $\mathrm{BCMA}^{-} \mathrm{TACI}^{+}$ myeloma cells could be eliminated by APRIL-based CAR-T cells therapy. It means that APRIL-based CAR-T cells can lead to tumor death, albeit BCMA downregulation.

The clinical examinations have been conducted to evaluate the dual-APRIL-based CAR-T cells, developing to target both BCMA and TACI that expressed on myeloma cells (NCT03287804) [143, 145]. Moreover, according to recent research, $\mathrm{T}$ regulatory cells (Tregs) expressing TACI can be suppressed by APRIL-based CAR-T cells, leading to the eradication of MM cells in an indirect manner [146].

\section{GPRC5D-CAR-T cell}

GPRC5D refers to a myeloma cell surface antigen that is a member of the human orphan family $G$ proteincoupled receptor [147]. GPRC5D is generally expressed on $\mathrm{CD} 138^{+} \mathrm{MM}$ cells and hair follicle cells. Recently, GPRC5D has been considered an attractive target antigen for CAR-T Cell therapy in MM patients $[148,149]$. Nevertheless, GPRC5D mRNA expression has only been detected on BM cells of MM cases, but its protein expression has not been found on myeloma cells by flow cytometry [150]. However, interestingly, GPRC5D expression on $98 \%$ of the $\mathrm{CD} 138^{+}$cells has been reported using the quantitative immunofluorescence method [149].

It has been proven that treating MM patients with BCMA-directed-CAR-T cell can be experienced with an antigen-loss relapse in the murine BCMA antigen escape model. This could improve using the GPRC5D-CAR-T cells $[149,151]$. Accordingly, a phase I clinical trial study has been designed to investigate the efficacy of GPRC5D-CAR-T cell therapy in RRMM patients following the BCMA-directed-CAR-T cell therapy [149].

In another performed study by Smith et al. [149], engineered GPRC5D-CAR-T cell revealed powerful anti-MM responses against human $\mathrm{MM}$ cell lines $\left(\mathrm{ffLuc}^{+}\right)$xenografted in the NSG mice. Thereby, the GPRC5D-CAR-T cell would effectively contribute to MM treatment.

\section{Integrin- $\beta 7-C A R-T$ cell}

Glycosylation or conformational modifications are considered post-translational processes which can convert the non-cancer-specific target epitopes to specific types. It significantly contributes to select appropriate target antigens in MM. Integrin- $\beta 7$ is such an example of a post-translational MM target antigen that more than 10, 000 hybridomas have been detected by screening against myeloma cells [152]. Among several designated therapies in MM patients, MMG49 mAb has been developed to potentially target a small fraction of $\mathrm{CD}_{1} 9^{+} \mathrm{B}$ cells and tumor-specific conformation of integrin- $\beta 7$. Antiintegrin- $\beta 7$ CAR- $T$ cell constructed by MMG49 (derived from $\mathrm{ScFv}$ ) was investigated against myeloma cells in vitro. This type of CAR-T cell could powerfully eradicate integrin- $\beta 7^{+}$MM cells by secreting the IFN $\gamma$ and IL-2 cytokines. Afterward, no tumor cell could escape, so rarely a malignant hematopoietic cell was seen [152].

\section{CD1d-CAR-T cell}

CD1d is related to the MHC class I-like molecule known as another target antigen that is overexpressed on the premalignant and early stage of MM cells. In the advanced stage of the disease, although, the CD1d expression is decreased. CD1d presents the glycolipids to NKT cells, a similar way to the antigen-presenting cells mediate it by MHC [153]. In this regard, to target CD1d ${ }^{+}$ MM cells, CD19-CAR-NKT cell has been developed with the capability of targeting both CD1d and CD19 antigens on myeloma cells. This type of CAR-T cell indicated the efficient anti-tumor response in comparison with anti-CD19 CAR-T cell monotherapy. As an advantage, this anti-CD19 CAR-NKT cell therapy indicated no cytotoxicity on monocytes, resulting in an elevated expression of CD1d among blood cells [154]. It has been suggested that CD1d inducer drugs, such as ATRA and EZH2 inhibitors, would help to improve the efficacy of CAR-T cell therapy as a combinational treatment approach [154]. Consequently, engineering the NKT cellbased CAR-T cells can be a prominent approach to target $\mathrm{CD} 1 \mathrm{~d}^{+} \mathrm{MM}$ cells in the early stages of the disease. 


\section{CD299-CAR-T cell}

CD299 receptor called SLAMF3, or Ly9, belongs to the SLAM family. Regardless of MM stage and contributed treatments on MM patients, CD299 is homogeneously and stably expressed on MM cells which is indispensable for MM cell survival [155-157]. It also has a positive expression on CD19-CD138-negative MM cells known as a drug-resistant MM cell population [157, 158]. From this point of view, CD299-targeted CAR-T cells can be generated to attack both masses of MM cells and remain MM cells which is resistant to chemotherapy. Firstly, in a preclinical study, Atanackovic et al. [158] have engineered CD229-CAR-T cell and investigated its functionality against MM cells. As a result, CD299-CAR-T cell has been applied potent anti-tumor cytotoxicity on malignant CD299 ${ }^{+}$MM cell lines with the least effect on healthy $\mathrm{B}$ and $\mathrm{T}$ cells.

\section{MM resistance or relapse after CAR-T therapy}

Although CAR-T cell therapy may cause relapse or resistance events, this approach has a potentially curative impact to treat MM patients. Cancer cell development accompanied by a lower antigen expression and loss of antigen can be considered reasons for MM resistance or relapse following CAR-T cell therapy which has been documented in multiple preclinical and clinical studies $[61,159,160]$. As an example, the reduction of BCMA antigen on myeloma cells has been observed after CAR$\mathrm{T}$ cell therapy. It can be suggested that targeting the multiple target antigens on tumor cells instead of only one antigen using the bi/tri-specific or multi-targeted CAR-T cells can solve the resistance/relapse problems. In a study by Yan et al., CD19/BCMA CAR-T cell as a dual-targeting CAR was evaluated in RRMM patients, which $100 \%$ overall response rate was reported after treatment [75].

The other cause of resistance/relapse in MM may be due to insufficient access of CAR-T cell to MM cells. MM cells have been emerged to locate in the microenvironment of bone marrow in the context of multiple extracellular matrix proteins which protect MM cells from CAR-T cell attack and diminish their accessibility to tumor cells [161]. Accordingly, in B cell lymphomabearing mice, CD19-CAR-T cell was traced whether reach to tumor site or not. Findings revealed that CAR$\mathrm{T}$ cells were decoyed in the lungs instead of reaching the target site [162]. On the other hand, MM cells provide an appropriate condition to evade immune system responses, and CAR-T cell attack through the increased level of immunosuppressive factors and cells, including fibroblast growth factor (FGF), VEGF, stromal cellderived factor (SDF)-1 $\alpha$, HGF, Treg cells, and myeloidderived suppressor cells (MDSCs) [163-166].
As a postulation, CAR-T cell with no prolonged persistence may be a reliable reason for its insufficient efficacy that leads to MM relapse after CAR-T cell therapy. Based on some previous clinical trial studies in acute and chronic lymphocytic leukemia, there is a marked relationship between CD19-CAR T cell anti-tumor response, and CAR-T cell expansion and persistence [167, 168]. However, some others reported permanent antitumor responses, even the absence of CAR-T cells [169]. Also, the correlation between bb2121-CAR-T cell persistence and response has been evidenced in a previous study. As a result, in $20 \%$ of cases, over 1 -year persistence was reported using bb2121-CAR-T cell. In this regard, a considerable frequency of CAR-T cells was found in patients treated with CAR-T cells after 28 days [63]. These described data are also consistent with MM patients achieving CAR-T cell treatment.

Moreover, MDSCs are identified as immunosuppressive cells leading to tumor progression. Augmented levels of MDSCs in the MM microenvironment decrease the immune factor infiltration into the tumor site and subsequently enhance the angiogenesis and tumor burden $[170,171]$. In a combinational treatment of CAR-T cell along with NK cells has been shown that infusion of NK cells was led to MDSC eradication through targeting NKG2D and raised the survival of solid tumor bearing in mice [172].

\section{CAR-T cell side effects and safety increasing solutions}

Like other cancer treatment approaches, adverse effects of CAR $\mathrm{T}$ cell therapy have been reported in several preclinical and clinical trial studies that cause the healthy tissue malfunction. Cytokine release syndrome (CRS), tumor lysis syndrome, neurotoxicity, anaphylaxis, prolonged cytopenia, hematological toxicity, on-target/offtumor toxicity, disease resistance/relapse, insertional oncogenesis, and hypogammaglobulinemia are the common instances of side effects which mostly occur due to CAR-T cell over-activation.

In treated patients with MM by CAR-T cell, lower grades of CRS and neurotoxicity are considered the most prevalent adverse effects. Same as other malignancies, mentioned toxicities in MM patients could be controlled using the anti-IL- 6 mAb (tocilizumab) and corticosteroids. Also, a $\mathrm{T}$ cell antigen coupler has been developed to recognize the target antigen in an MHC-independent manner and engage the naive TCR response, which has indicated lower toxicities than CAR-T cells [173].

The other well-known problem in MM CAR-T cell therapy is the absence of specific target antigens on tumoral plasma cells resulting in undesirable toxicities on healthy cells. Unlikely, the powerful response of CAR-T cells to healthy cells expressing a lower level of the 
target antigen elicits the on-target/off-tumor toxicity $[174,175]$. To solve the problem, a proper target antigen or epitope should be identified by CAR-T cell.

Hence, some controllable regimens have been developed to mitigate the on-target/off-tumor toxicity, like the suicide switches mechanism. To overcome CAR-T cells over-activity problem, the inducible caspase 9 (iCas9) can be used as a proapoptotic suicide gene to protect healthy cells. iCas9 is dimerized and activates the apoptosis signaling through the administration of AP1903, a small switching molecule leading to CAR-T cell stops. iCas 9 shows the $90 \%$ clearance of administered CAR-T cells following the AP1903 infusion after $12 \mathrm{~h} \mathrm{[176].}$

The RNA-based mechanism or bacterial-derived effectors can be applied as CAR-T cell manageable systems under the tetracycline-inducible promoter control. In the RNA-based system under the control of tetracycline, the secretion of IL-2 cytokine depends on the administration of doxycycline [177]. To trigger transient inactivation of the TCR signaling, OspF protein can be utilized as a bacterial-derived effector under control of tetracycline. This effect conducts the T cells to stop after doxycycline administration. These controlling regimens have not been carried out in using CAR-T cells [178]. Furthermore, exerting Ab-based switches, comprising of CD20, epidermal growth factor receptor (EGFR), and cmyc in CAR-T cell structure which can induce death in engineered $\mathrm{T}$ cells through the infusion of monoclonal antibodies against mentioned switches tags $[179,180]$.

Also, using the switch-on-based strategies to activate CAR-T cells in a controllable manner can promote the efficacy and safety of CARs. The split structure of CAR is constructed from separate activator and costimulatory portions, which can be assembled and activate the signaling through the administration of the small molecule. According to an investigation by $\mathrm{Wu}$ et al., a split antiCD19 CAR-T cell was engineered, and outcomes indicated several efficient responses in vitro and in vivo examinations. This split strategy would be implemented in MM-targeted CAR-T cells to enhance the safety and efficacy [181].

Inhibitory CARs (iCARs) are another inhibitory mechanism that can halt CAR-T cell activity based on PD-1 or CTLA-4 inhibitory checkpoints. Recognizing the antigen that is expressed on healthy cells by iCAR induces the inhibitory signaling of CAR, which is specific to the target antigen on tumor cells [182]. The results of a meta-analysis demonstrated the potential effectiveness of CAR-T cell therapy in patients with hematologic malignancies; however, no overall signal regarding the relationship between CAR-T cells and solid tumor trials published so far. The results of this study can take part in making assistance to physicians, patients by determining the pros- and cons-associated with CAR-T cell therapy [183].

Finally, as a suggestion, using multi-targeted CAR-T cells and described inhibitory systems would be promising to robust CAR-T cell function. Exerting dual, tandem, or universal CARs has been shown to contribute to recognizing target antigens on tumor cells, simultaneously. They will be attractive due to provide an effective response without toxicity on healthy tissues [184-187]. However, the determination of proper and potent antigens on MM cells is a difficult challenge that affected the success of CAR-T cell therapy in MM patients.

\section{Allogenic CAR-T cells}

Using allogeneic CAR-T cell therapy also may be useful in treating patients with progressive disease or for immediate necessary to CAR-T cells. In this case, engineering allogeneic CAR-T cell-derived from healthy donors would pave the patients' necessity for available and feasible CAR $\mathrm{T}$ cell treatment. In the in vitro study and xenograft mice models, anti-BCMA allogeneic CAR T cell has been used to treat MM, which showed encouraging results. Since the high risk of graft-versus-host disease (GVHD) is a disadvantage of using this type of CAR-T cell, the TRAC gene has been removed from $T$ cell by transcription activator-like effector nucleases (TALEN) editing strategy to minimize the GVHD risk [188]. Moreover, to perform selective lymphodepletion in a host, anti-CD52 mAb has been applied to knock out the CD52 gene in host lymphocytes [188]. Another example of applying the TALEN strategy to diminish the risk of GVHD is the SLAM7-CAR-T cell under clinical development that edited by eliminating the TRAC gene [132].

\section{The future direction of CAR-T therapy in multiple myeloma}

Despite recent advances, there is no chemotherapy approach for patients suffering from multiple myeloma. In this regard, CAR-T cells are engineered $T$ cells having lymphocyte-like signaling molecules which have been used not only in blood malignancies but also in various types of cancer against a range of target genes that are specifically expressed in malignant cells, so they have been introduced as a potential therapeutic goal to strengthen the immune system against malignant cells. Besides, CAR-modified T cell clinical trials have yielded unprecedented results in treating patients with $\mathrm{MM}$ and are expected to have a great influence by determining the suitable targets and reducing off-target effects [43]. The potency of CAR-T cell therapy in long-term multiple myeloma disease control, if fully comprehended, can have a transformative effect in this area. However, studies in the field of hematological malignancies are 
needed to identify new targets along with new combinational therapy. There are more than four hundred clinical trials focused on CAR-T cells in hematological malignancies along with the thousands of combinational therapy in this area. The challenge may be to determine better targets and/or most efficacious combinational therapy [43].

\section{Concluding remarks}

In recent decades, cancer progresses occurred and substantial strides forward have been taken from investigations to encouraging clinical trials on the ground of cancer treatment. With the advent of ACT-based treatments, fighting against cancer has achieved impressive successes. CAR-T cell therapy has been considered a potent part of adoptive cell therapy-based approaches which has created a breakthrough for treating hematological and solid tumors using the modified recombinant target antigen receptor fused to $\mathrm{T}$ cells. Although there are various barriers responsible for CAR-T cell failure in solid tumors, promising results have been reported in hematological malignancies up to now.

There are multiple target antigens identified for targeting by CAR-T cells in hematological malignancies, in which anti-CD19-CAR-T cell has been known as the most used CAR-T cell. Multiple myeloma is a hematological malignancy defined by the increased level of transformed monoclonal plasma cells. Despite the considerable achievement of using therapeutic mAbs and drugs in MM, including bortezomib, carfilzomib, ixazomib, panobinostat, thalidomide, lenalidomide, pomalidomide, daratumumab, and elotuzumab, but most patients face relapse and resistance problems after these advanced treatments.

New horizons have been found for treating MM cases by the emergence of CAR-T cell therapy. MM has demonstrated promising reactions to CAR-T cell therapy, despite the difficulties in finding suitable target antigens. Based on several preclinical and clinical trial studies, multiple CAR-T cells have been developed to target different antigens expressing on myeloma cells.

As results of CAR-T cell therapy in vitro and in vivo investigations, potent anti-tumor cytotoxicity, cytokine production, and tumor escape prevention of CAR-T cells along with an encouraging overall response rate have been reported in most patients.

Among others, BCMA, CD19, CD38, and CD138 expressing on myeloma cells are mostly targeted by CART cells. Anti-BCMA CAR-T cell has been mostly investigated in many investigations with encouraging implications against MM. Despite obtaining attractive and hopeful results, recognizing the specific target antigens, preventing the resistance/relapse after CAR- $T$ cell therapy, and generating effective anti-tumor responses with high safety and efficacy remain as challenges in MM CAR-T cell therapy.

CRS and on-target/off-tumor toxicity have been indicated as the most common side effects of CAR-T cell therapy in MM. Accordingly, different approaches have been developed and applied to robust the safety and efficacy of CAR-T cells. Multi-targeted or bispecific CAR-T cells and inhibitory strategies, including suicide genes, Ab-based-switches, iCARs, and CRISPR/Cas9 systems are examples of safety solutions. Also, to provide a cheap, available, and a sufficient number of CAR-T cells for MM treatment, using allogenic CAR-T cells would be a helpful suggestion, particularly in progressive situations.

In conclusion, CAR-T cells by directing against a variety of targets can be utilized as warrior heroes for treating patients diagnosed with MM by the contribution of the other CAR-T cells or therapeutic approaches. However, conducting several investigations is critically required to recognize the predisposed and specific target antigens, modify the potent CAR-T cells, and improve the safety of CARs, which would be helpful to performing the impressive response of CAR-T cells against tumor cells.

\section{Abbreviations \\ CAR: Chimeric antigen receptor; GvHD: Graft-versus-host disease; CAR- NK: CAR-transduced NK cells; NK cells: Natural killer cells; ACTs: Adaptive cell therapies; NHL: Non-Hodgkin lymphomas; DLBCL: Diffused large B cell lymphoma; ALL: Lymphoblastic leukemia; MM: Multiple myeloma; AML: Acute myeloid leukemia; CRS: Cytokine release syndrome; CTLs: Cytotoxic T lymphocytes; iCAS9: Inducible caspase 9}

\section{Acknowledgements}

Not applicable.

\section{Authors' contributions}

All authors contributed to the conception and the main idea of the work. S.T., N.SH., R.N.M., H.S.R., and F.M. drafted the main text, figures, and tables, F.M.KH., M.J., M.S.C., and Y.P. supervised the work and provided the comments and additional scientific information. R.M., D.K., A.M., and A.V.Y. also reviewed and revised the text. All authors read and approved the final version of the work to be published.

\section{Funding}

No funders.

Availability of data and materials Not applicable.

\section{Declarations}

Ethics approval and consent to participate Not applicable.

Consent for publication

Not applicable.

\section{Competing interests}

The authors declare that they have no competing interests.

\section{Author details}

'Department of Hematology, Faculty of Medicine, Tabriz University of Medical Sciences, Tabriz, Iran. ${ }^{2}$ Department of Immunology, Faculty of 
Medicine, Zanjan University of Medical Sciences, Zanjan, Iran. ${ }^{3}$ Department of Physiology, College of Medicine, University of Suleimanyah, Sulaymaniyah, Iraq. ${ }^{4}$ Director of Research Institute "MitoKey", Moscow State Medical University, Moscow, Russian Federation. ${ }^{5}$ Tyumen State Medical University, Tyumen, Russian Federation. ${ }^{6}$ Department of Prosthetic Dentistry, Sechenov First Moscow State Medical University, Trubetskaya St., 8-2, Moscow, Russian Federation 119991. 'Department of Immunology, Faculty of Medicine, Tabriz University of Medical Sciences, Tabriz, Iran. ${ }^{8}$ Immunology Research Center, Tabriz University of Medical Sciences, Tabriz, Iran. ${ }^{9}$ DigiCare Behavioral Research, Casa Grande, AZ, USA. ${ }^{10}$ Faculty Affairs, Taneja College of Pharmacy, University of South Florida, Tampa, FL, USA. ${ }^{11}$ Faculty of Pharmacy, Airlangga University, Surabaya, Indonesia. ${ }^{12}$ Bone Marrow Transplant Center, Hiwa Cancer Hospital, Suleimanyah, Iraq. ${ }^{13}$ Toxicology and Chemotherapy Unit (G401), German Cancer Research Center, 69120 Heidelberg, Germany. ${ }^{14}$ Stem Cell Research Center, Tabriz University of Medical Sciences, Tabriz, Iran. ${ }^{15}$ Department of Virology, Pasteur Institute of Iran, Tehran, Iran.

Received: 23 January 2021 Accepted: 11 March 2021

Published online: 29 March 2021

\section{References}

1. Kumar SK, Rajkumar V, Kyle RA, van Duin M, Sonneveld P, Mateos MV, Gay F, Anderson KC. Multiple myeloma. Nat Rev Dis Prim. 2017:3:17046.

2. Sahara N, Takeshita A, Shigeno K, Fujisawa S, Takeshita K, Naito K, Ihara M, Ono T, Tamashima S, Nara K. Clinicopathological and prognostic characteristics of CD56-negative multiple myeloma. Bri J Haematol. 2002; 117:882-5.

3. Mateos MV, Ludwig H, Bazarbachi H, Beksac M, Bladé J, Boccadoro M, Cavo M, Delforge M, Dimopoulos MA, Facon T. Insights on multiple myeloma treatment strategies. HemaSphere. 2019;3:e163.

4. Kumar SK, Dispenzieri A, Lacy MQ, Gertz MA, Buadi FK, Pandey S, Kapoor P Dingli D, Hayman SR, Leung N. Continued improvement in survival in multiple myeloma: changes in early mortality and outcomes in older patients. Leukemia. 2014;28:1122-8.

5. De Weers M, Tai Y-T, Van Der Veer MS, Bakker JM, Vink T, Jacobs DC, Oomen LA, Peipp M, Valerius T, Slootstra JW. Daratumumab, a novel therapeutic human CD38 monoclonal antibody, induces killing of multiple myeloma and other hematological tumors. J Immunol. 2011;186:1840-8.

6. Lonial S, Dimopoulos M, Palumbo A, White D, Grosicki S, Spicka I, WalterCroneck A, Moreau P, Mateos M-V, Magen H. Elotuzumab therapy for relapsed or refractory multiple myeloma. N Engl J Med. 2015;373:621-31.

7. Gattinoni L, Powell DJ, Rosenberg SA, Restifo NP. Adoptive immunotherapy for cancer: building on success. Nat Rev Immunol. 2006;6:383-93.

8. Elahi R, Khosh E, Tahmasebi S, Esmaeilzadeh A. Immune cell hacking: challenges and clinical approaches to create smarter generations of chimeric antigen receptor T cells. Front Immunol. 2018;9:1717.

9. A. Esmaeilzadeh, S. Tahmasebi, S.S. Athari, Chimeric antigen receptor -T cell therapy: spplications and challenges in treatment of allergy and asthma, Biomedicine \& pharmacotherapy = Biomedecine \& pharmacotherapie, 123 (2020) 109685

10. Shirafkan N, Shomali N, Kazemi T, Shanehbandi D, Ghasabi M, Baghbani E, Ganji M, Khaze V, Mansoori B, Baradaran B. microRNA-193a-5p inhibits migration of human HT-29 colon cancer cells via suppression of metastasis pathway. J Cell Biochem. 2019;120:8775-83.

11. Tahmasebi S, Elahi R, Esmaeilzadeh A. Solid tumors challenges and new insights of CAR T cell engineering. Stem Cell Rev Rep. 2019;15:619-36.

12. Au R. Immunooncology: can the right chimeric antigen receptors T-cell design be made to cure all types of cancers and will it be covered?. J Pharmaceutics. 2017;2017:7513687.

13. Gross G, Waks T, Eshhar Z. Expression of immunoglobulin-T-cell receptor chimeric molecules as functional receptors with antibody-type specificity. Proc National Acad Sci. 1989;86:10024-8.

14. June $\mathrm{CH}$, Sadelain M. Chimeric antigen receptor therapy. N Engl J Med. 2018;379:64-73

15. Sadelain M. CD19 CAR T cells. Cell. 2017;171:1471.

16. Gahrton G, Svensson H, Cavo M, Apperley J, Bacigalupo A, Björkstrand B, Blade J, Cornelissen J, De Laurenzi A, Facon T. Progress in allogeneic bone marrow and peripheral blood stem cell transplantation for multiple myeloma: a comparison between transplants performed 1983-93 and 1994-98 at European Group for Blood and Marrow Transplantation centres. Br J Haematol. 2001;113:209-16.
17. Dhakal B, Vesole D, Hari P. Allogeneic stem cell transplantation for multiple myeloma: is there a future? Bone Marrow Transplant. 2016;51:492-500.

18. San Miguel JF, Garcia-Sanz R, Gonzalez M, Orfao A. Immunophenotype and DNA cell content in multiple myeloma. Baillière's Clin Haematol. 1995;8:735-59.

19. Nelson AL, Dhimolea E, Reichert JM. Development trends for human monoclonal antibody therapeutics. Nat Rev Drug Discov. 2010;9:767-74.

20. Lambert JM. Drug-conjugated antibodies for the treatment of cancer. $\mathrm{Br}$ J Clin Pharmacol. 2013;76:248-62.

21. Chung $\mathrm{C}$. Role of immunotherapy in targeting the bone marrow microenvironment in multiple myeloma: an evolving therapeutic strategy. Pharmacotherapy. 2017;37:129-43.

22. Kelly KR, Chanan-Khan A, Heffner LT, Somlo G, Siegel DS, Zimmerman T, Karnad A, Munshi NC, Jagannath S, Greenberg AL. Indatuximab ravtansine (BT062) in combination with lenalidomide and low-dose dexamethasone in patients with relapsed and/or refractory multiple myeloma: clinical activity in patients already exposed to lenalidomide and bortezomib. Blood. 2014; 124:4736.

23. Baeuerle PA, Reinhardt C. Bispecific T-cell engaging antibodies for cancer therapy. Cancer Res. 2009;69:4941-4.

24. Zou J, Chen D, Zong Y, Ye S, Tang J, Meng H, An G, Zhang X, Yang L. Immunotherapy based on bispecific T-cell engager with hlgG 1 Fc sequence as a new therapeutic strategy in multiple myeloma. Cancer Sci. 2015;106:512-21.

25. Dong H, Strome SE, Salomao DR, Tamura H, Hirano F, Flies DB, Roche PC, Lu J, Zhu G, Tamada K, Lennon VA, Celis E, Chen L. Tumor-associated B7-H1 promotes T-cell apoptosis: a potential mechanism of immune evasion. Nat Med. 2002;8:793-800.

26. Tamura H, Ishibashi M, Yamashita T, Tanosaki S, Okuyama N, Kondo A, Hyodo $\mathrm{H}$, Shinya E, Takahashi H, Dong H. Marrow stromal cells induce B7$\mathrm{H} 1$ expression on myeloma cells, generating aggressive characteristics in multiple myeloma. Leukemia. 2013;27:464-72.

27. Lesokhin AM, Ansell SM, Armand P, Scott EC, Halwani A, Gutierrez M, Millenson MM, Cohen AD, Schuster SJ, Lebovic D. Nivolumab in patients with relapsed or refractory hematologic malignancy: preliminary results of a phase Ib study. J Clin Oncol. 2016;34:2698.

28. Badros A, Hyjek E, Ma N, Lesokhin A, Dogan A, Rapoport AP, Kocoglu M, Lederer E, Philip S, Milliron T. Pembrolizumab, pomalidomide, and low-dose dexamethasone for relapsed/refractory multiple myeloma. Blood. 2017;130: 1189-97.

29. Bae J, Smith R, Daley J, Mimura N, Tai Y-T, Anderson KC, Munshi NC. Myeloma-specific multiple peptides able to generate cytotoxic $\mathrm{T}$ lymphocytes: a potential therapeutic application in multiple myeloma and other plasma cell disorders. Clin Cancer Res. 2012;18:4850-60.

30. Bae J, Prabhala R, Voskertchian A, Brown A, Maguire C, Richardson P, Dranoff G, Anderson KC, Munshi NC. A multiepitope of XBP1, CD138 and CS1 peptides induces myeloma-specific cytotoxic T lymphocytes in T cells of smoldering myeloma patients. Leukemia. 2015;29:218-29.

31. Rosenblatt J, Avivi I, Vasir B, Uhl L, Munshi NC, Katz T, Dey BR, Somaiya P, Mills $\mathrm{H}$, Campigotto F. Vaccination with dendritic cell/tumor fusions following autologous stem cell transplant induces immunologic and clinical responses in multiple myeloma patients. Clin Cancer Res. 2013;19:3640-8.

32. Rosenblatt J, Vasir B, Uhl L, Blotta S, MacNamara C, Somaiya P, Wu Z, Joyce $\mathrm{R}$, Levine JD, Dombagoda D. Vaccination with dendritic cell/tumor fusion cells results in cellular and humoral antitumor immune responses in patients with multiple myeloma. Blood. 2011;117:393-402.

33. Vallet $\mathrm{S}$, Pecherstorfer M, Podar K. Adoptive cell therapy in multiple myeloma. Expert Opin Biol Ther. 2017;17:1511-22.

34. Brentjens RJ, Davila ML, Riviere I, Park J, Wang X, Cowell LG, Bartido S, Stefanski J, Taylor C, Olszewska M. CD19-targeted T cells rapidly induce molecular remissions in adults with chemotherapy-refractory acute lymphoblastic leukemia. Sci Transl Med. 2013;5:177ra138.

35. Garfall AL, Maus MV, Hwang W-T, Lacey SF, Mahnke YD, Melenhorst JJ, Zheng Z, Vogl DT, Cohen AD, Weiss BM. Chimeric antigen receptor T cells against CD19 for multiple myeloma. N Engl J Med. 2015;373:1040-7.

36. Grupp SA, Kalos M, Barrett D, Aplenc R, Porter DL, Rheingold SR, Teachey DT, Chew A, Hauck B, Wright JF. Chimeric antigen receptor-modified T cells for acute lymphoid leukemia. N Engl J Med. 2013;368:1509-18.

37. Lee DW, Kochenderfer JN, Stetler-Stevenson M, Cui YK, Delbrook C, Feldman SA, Fry TJ, Orentas R, Sabatino M, Shah NN. T cells expressing CD19 chimeric antigen receptors for acute lymphoblastic leukaemia in children and young adults: a phase 1 dose-escalation trial. Lancet. 2015;385:517-28. 
38. Neelapu SS, Locke FL, Bartlett NL, Lekakis LJ, Miklos DB, Jacobson CA, Braunschweig I, Oluwole OO, Siddiqi T, Lin Y. Axicabtagene ciloleucel CAR T-cell therapy in refractory large B-cell lymphoma. N Engl J Med. 2017;377: 2531-44.

39. Hock RA, Miller AD. Retrovirus-mediated transfer and expression of drug resistance genes in human haematopoietic progenitor cells. Nature. 1986; 320:275-7.

40. Johnson LA, June $\mathrm{CH}$. Driving gene-engineered $\mathrm{T}$ cell immunotherapy of cancer. Cell Res. 2017;27:38-58.

41. Toneguzzo F, Keating A. Stable expression of selectable genes introduced into human hematopoietic stem cells by electric field-mediated DNA transfer. Proc Natl Acad Sci. 1986;83:3496-9.

42. Schaefer-Ridder M, Wang Y, Hofschneider PH. Liposomes as gene carriers: efficient transformation of mouse $L$ cells by thymidine kinase gene. Science. 1982;215:166-8

43. Marofi F, Motavalli R, Safonov VA, Thangavelu L, Yumashev AV, Alexander M, Shomali N, Chartrand MS, Pathak Y, Jarahian M. CAR T cells in solid tumors: challenges and opportunities. Stem Cell Res Ther. 2021;12:1-16.

44. Srivastava S, Riddell SR. Engineering CAR-T cells: design concepts. Trends Immunol. 2015;36:494-502.

45. Tahmasebi $\mathrm{S}$, Elahi R, Khosh $\mathrm{E}_{1}$ Esmaeilzadeh A. Programmable and multitargeted CARs: a new breakthrough in cancer CAR-T cell therapy. Clin Transl Oncol. 2020.

46. Chmielewski M, Hombach AA, Abken H. Of CAR s and TRUCK s: chimeric antigen receptor (CAR) T cells engineered with an inducible cytokine to modulate the tumor stroma. Immunol Rev. 2014;257:83-90.

47. Esmaeilzadeh A, Tahmasebi S, Athari SS. Chimeric antigen receptor-T cell therapy: applications and challenges in treatment of allergy and asthma. Biomed Pharmacother. 2020;123:109685.

48. Zhao Z, Chen Y, Francisco NM, Zhang Y, Wu M. The application of CAR-T cell therapy in hematological malignancies: advantages and challenges. Acta Pharm Sin B. 2018;8:539-51.

49. Kochenderfer JN, Wilson WH, Janik JE, Dudley ME, Stetler-Stevenson M, Feldman SA, Maric I, Raffeld M, Nathan D-AN, Lanier BJ. Eradication of Blineage cells and regression of lymphoma in a patient treated with autologous T cells genetically engineered to recognize CD19. Blood. 2010; 116:4099-102

50. Porter DL, Levine BL, Kalos M, Bagg A, June $\mathrm{CH}$. Chimeric antigen receptormodified T cells in chronic lymphoid leukemia. N Engl J Med. 2011;365:725-33.

51. Fry TJ, Shah NN, Orentas RJ, Stetler-Stevenson M, Yuan CM, Ramakrishna S, Wolters P, Martin S, Delbrook C, Yates B. CD22-targeted CAR T cells induce remission in B-ALL that is naive or resistant to CD19-targeted CAR immunotherapy. Nat Med. 2018;24:20.

52. Haso W, Lee DW, Shah NN, Stetler-Stevenson M, Yuan CM, Pastan $\mathbb{H}_{\text {, }}$ Dimitrov DS, Morgan RA, FitzGerald DJ, Barrett DM. Anti-CD22-chimeric antigen receptors targeting B-cell precursor acute lymphoblastic leukemia. Blood. 2013;121:1165-74.

53. Till BG, Jensen MC, Wang J, Chen EY, Wood BL, Greisman HA, Qian X, James SE, Raubitschek A, Forman SJ. Adoptive immunotherapy for indolent nonHodgkin lymphoma and mantle cell lymphoma using genetically modified autologous CD20-specific T cells. Blood. 2008;112:2261-71.

54. Zhang W-y, Wang Y, Guo Y-I, Dai H-r, Yang Q-m, Zhang Y-j, Zhang Y, Chen M-X, Wang C-m, Feng K-c. Treatment of CD20-directed chimeric antigen receptor-modified T cells in patients with relapsed or refractory B-cell nonHodgkin lymphoma: an early phase lla trial report. Signal Transduct Target Ther. 2016;1:1-9.

55. Tai Y-T, Anderson KC. Targeting B-cell maturation antigen in multiple myeloma. Immunotherapy. 2015;7:1187-99.

56. Tai Y-T, Acharya C, An G, Moschetta M, Zhong MY, Feng X, Cea M, Cagnetta A, Wen $\mathrm{K}$, van Eenennaam $\mathrm{H}$. APRIL and BCMA promote human multiple myeloma growth and immunosuppression in the bone marrow microenvironment. Blood. 2016:127:3225-36.

57. Topp MS, Duell J, Zugmaier G, Attal M, Moreau P, Langer C, Kroenke J, Facon T, Einsele H, Munzert G. Treatment with AMG 420, an anti-B-cell maturation antigen (BCMA) bispecific T-cell engager (BiTE ${ }^{\circledast}$ ) antibody construct, induces minimal residual disease (MRD) negative complete responses in relapsed and/or refractory (R/R) multiple myeloma (MM) patients: results of a first-in-human $(\mathrm{FlH})$ phase I dose escalation study. Blood. 2018;132:1010.

58. Trudel S, Lendvai N, Popat R, Voorhees PM, Reeves B, Libby EN, Richardson PG, Anderson LD Jr, Sutherland HJ, Yong K. Targeting B-cell maturation antigen with GSK2857916 antibody-drug conjugate in relapsed or refractory multiple myeloma (BMA117159): a dose escalation and expansion phase 1 trial. Lancet Oncol. 2018;19:1641-53.

59. Lee L, Bounds D, Paterson J, Herledan G, Sully K, Seestaller-Wehr LM, Fieles WE, Tunstead J, McCahon L, Germaschewski FM. Evaluation of B cell maturation antigen as a target for antibody drug conjugate mediated cytotoxicity in multiple myeloma. Bri J Haematol. 2016;174:911-22.

60. Sanchez E, Gillespie A, Tang G, Ferros M, Harutyunyan NM, Vardanyan S, Gottlieb J, Li M, Wang CS, Chen H. Soluble B-cell maturation antigen mediates tumor-induced immune deficiency in multiple myeloma. Clin Cancer Res. 2016;22:3383-97.

61. Brudno JN, Maric I, Hartman SD, Rose JJ, Wang M, Lam N, Stetler-Stevenson M, Salem D, Yuan C, Pavletic S. T cells genetically modified to express an anti-B-cell maturation antigen chimeric antigen receptor cause remissions of poor-prognosis relapsed multiple myeloma. J Clin Oncol. 2018;36:2267.

62. Friedman KM, Garrett TE, Evans JW, Horton HM, Latimer HJ, Seidel SL, Horvath CJ, Morgan RA. Effective targeting of multiple B-cell maturation antigen-expressing hematological malignances by anti-B-cell maturation antigen chimeric antigen receptor T cells. Human Gene Ther. 2018;29:585-601.

63. Raje N, Berdeja J, Lin Y, Siegel D, Jagannath S, Madduri D, Liedtke M, Rosenblatt J, Maus MV, Turka A. Anti-BCMA CAR T-cell therapy bb2121 in relapsed or refractory multiple myeloma. N Engl J Med. 2019;380:1726-37.

64. Shah N, Alsina M, Siegel DS, Jagannath S, Madduri D, Kaufman JL, Turka A Lam LP, Massaro M, Hege K. Initial results from a phase 1 clinical study of bb21217, a next-generation anti Bcma CAR T therapy. Blood. 2018;132:488.

65. Zhao W-H, Liu J, Wang B-Y, Chen Y-X, Cao X-M, Yang Y, Zhang Y-L, Wang F$X$, Zhang P-Y, Lei B. A phase 1, open-label study of LCAR-B38M, a chimeric antigen receptor $T$ cell therapy directed against B cell maturation antigen, in patients with relapsed or refractory multiple myeloma. J Hematol Oncol. 2018;11:1-8.

66. Gregory T, Cohen AD, Costello CL, Ali SA, Berdeja JG, Ostertag EM, Martin C, Shedlock DJ, Resler ML, Spear MA. Efficacy and safety of P-Bcma-101 CAR-T cells in patients with relapsed/refractory $(r / r)$ multiple myeloma (MM). Blood. 2018;132:1012.

67. Soulieres D, Cohen E, Le Tourneau C, Dinis J, Licitra L, Ahn MJ, Soria A, Machiels JP, Mach N, Mehra R. Abstract CT115: updated survival results of the KEYNOTE-040 study of pembrolizumab vs standard-of-care chemotherapy for recurrent or metastatic head and neck squamous cell carcinoma. Cancer Res. 2018;7:CT115.

68. Mailankody S, Ghosh A, Staehr M, Purdon TJ, Roshal M, Halton E, Diamonte C, Pineda J, Anant P, Bernal Y. Clinical responses and pharmacokinetics of MCARH171, a human-derived Bcma targeted CAR T cell therapy in relapsed/ refractory multiple myeloma: final results of a phase I clinical trial. Blood. 2018;132:959.

69. Xu J, Wang Q, Xu H, Gu C, Jiang L, Wang J, Wang D, Xu B, Mao X, Wang J. Anti-BCMA CAR-T cells for treatment of plasma cell dyscrasia: case report on POEMS syndrome and multiple myeloma. J Hematol Oncol. 2018;11:1-9.

70. Li C, Zhou X, Wang J, Hu G, Meng L, Hong Z, Chen L, Zhou J. Clinical responses and pharmacokinetics of fully human BCMA targeting CAR T cell therapy in relapsed/refractory multiple myeloma, clinical lymphoma. Myeloma Leukemia. 2019;19:e23-4.

71. Wang K, Wei G, Liu D. CD19: a biomarker for B cell development, lymphoma diagnosis and therapy. Exp Hematol Oncol. 2012;1:36.

72. Franqui-Machin R, Wendlandt EB, Janz S, Zhan F, Tricot G. Cancer stem cells are the cause of drug resistance in multiple myeloma: fact or fiction? Oncotarget. 2015;6:40496.

73. Johnsen HE, Bøgsted M, Schmitz A, Bødker JS, El-Galaly TC, Johansen P, Valent P, Zojer N, Van Valckenborgh E, Vanderkerken K. The myeloma stem cell concept, revisited: from phenomenology to operational terms. Haematologica. 2016;101:1451-9.

74. Koronyo Y, Biggs D, Barron E, Boyer DS, Pearlman JA, Au WJ, Kile SJ, Blanco A, Fuchs DT, Ashfaq A. Retinal amyloid pathology and proof-of-concept imaging trial in Alzheimer's disease. JCl insight. 2017;2:e93621.

75. Yan L, Shang J, Kang L, Shi X, Zhou J, Jin S, Yao W, Yao Y, Chen G, Zhu Z. Combined infusion of CD19 and Bcma-specific chimeric antigen receptor $T$ cells for RRMM: initial safety and efficacy report from a clinical pilot study. Blood. 2017;130:506

76. Shi X, Yan L, Shang J, Qu S, Kang L, Zhou J, Jin S, Yao W, Yao Y, Yan S. Tandom autologous transplantation and combined infusion of CD19 and Bcma-specific chimeric antigen receptor T cells for high risk MM: initial safety and efficacy report from a clinical pilot study. Blood. 2018;132:1009. 
77. Yan Z, Cao J, Cheng H, Qiao J, Zhang H, Wang Y, Shi M, Lan J, Fei X, Jin L. A combination of humanised anti-CD19 and anti-BCMA CAR T cells in patients with relapsed or refractory multiple myeloma: a single-arm, phase 2 trial. Lancet Haematol. 2019;6:e521-9.

78. Matsui W, Huff CA, Wang Q, Malehorn MT, Barber J, Tanhehco Y, Smith BD Civin $\mathrm{Cl}$, Jones RJ. Characterization of clonogenic multiple myeloma cells. Blood. 2004;103:2332-6.

79. Hutchinson AT, Jones DR, Raison RL. Preclinical and clinical development of an anti-kappa free light chain mAb for multiple myeloma. Mol Immunol. 2015;67:89-94.

80. Ramos CA, Savoldo B, Torrano V, Ballard B, Zhang H, Dakhova O, Liu E, Carrum G, Kamble RT, Gee AP. Clinical responses with T lymphocytes targeting malignancy-associated $\mathrm{k}$ light chains. J Clin Investig. 2016;126: 2588-96.

81. Patel K, Olivares S, Singh H, Hurton LV, Huls MH, Qazilbash MH, Kebriaei P, Champlin RE, Cooper LJ. Combination immunotherapy with NY-ESO-1specific CAR+ T cells with T-cell vaccine improves anti-myeloma effect. Blood. 2016;128:3366.

82. Schuberth P, Jakka G, Jensen S, Wadle A, Gautschi F, Haley D, Haile S, Mischo A, Held G, Thiel M. Effector memory and central memory NY-ESO-1specific re-directed T cells for treatment of multiple myeloma. Gene Ther. 2013;20:386-95.

83. Rapoport AP, Stadtmauer EA, Binder-Scholl GK, Goloubeva O, Vogl DT, Lacey SF, Badros AZ, Garfall A, Weiss B, Finklestein J. NY-ESO-1-specific TCRengineered T cells mediate sustained antigen-specific antitumor effects in myeloma. Nature Med. 2015;21:914.

84. Fernandez J, Deaglio S, Donati D, Beusan IS, Corno F, Aranega A, Forni M, Falini B, Malavasi F. Analysis of the distribution of human CD38 and of its ligand CD31 in normal tissues. J Biol Regul Homeost Agents. 1998;12:81-91.

85. Drent E, Groen RW, Noort WA, Themeli M, van Bueren JJL, Parren PW, Kuball J, Sebestyen Z, Yuan H, de Bruijn J. Pre-clinical evaluation of CD38 chimeric antigen receptor engineered $T$ cells for the treatment of multiple myeloma. Haematologica. 2016;101:616-25.

86. Lonial S, Weiss BM, Usmani SZ, Singhal S, Chari A, Bahlis NJ, Belch A, Krishnan A, Vescio RA, Mateos MV. Daratumumab monotherapy in patients with treatment-refractory multiple myeloma (SIRIUS): an open-label, randomised, phase 2 trial. Lancet. 2016;387:1551-60.

87. Martin T, Baz R, Benson DM, Lendvai N, Wolf J, Munster P, Lesokhin AM, Wack C, Charpentier E, Campana F. A phase 1b study of isatuximab plus lenalidomide and dexamethasone for relapsed/refractory multiple myeloma. Blood. 2017;129:3294-303.

88. Drent E, Themeli M, Poels R, de Jong-Korlaar R, Yuan H, de Bruijn J, Martens AC, Zweegman S, van de Donk NW, Groen RW. A rational strategy for reducing on-target off-tumor effects of CD38-chimeric antigen receptors by affinity optimization. Mol Ther. 2017;25:1946-58.

89. An N, Hou YN, Zhang QX, Li T, Zhang QL, Fang C, Chen H, Lee HC, Zhao YJ, Du X. Anti-multiple myeloma activity of nanobody-based anti-CD38 chimeric antigen receptor T cells. Mol Pharm. 2018;15:4577-88.

90. García-Guerrero E, Gogishvili T, Danhof S, Schreder M, Pallaud C, Pérez Simón JA, Einsele H, Hudecek M. Panobinostat induces CD38 upregulation and augments the antimyeloma efficacy of daratumumab. Blood. 2017;129: 3386-8.

91. Yoshida T, Mihara K, Takei Y, Yanagihara K, Kubo T, Bhattacharyya J, Imai C, Mino T, Takihara $Y$, Ichinohe T. All-trans retinoic acid enhances cytotoxic effect of T cells with an anti-CD38 chimeric antigen receptor in acute myeloid leukemia. Clin Transl Immunol. 2016;5:e116.

92. Liebisch P, Eppinger S, Schopflin C, Stehle G, Munzert G, Dohner H, Schmid M. CD44v6, a target for novel antibody treatment approaches, is frequently expressed in multiple myeloma and associated with deletion of chromosome arm 13q. Haematologica. 2005;90:489-93.

93. Tijink BM, Buter J, De Bree R, Giaccone G, Lang MS, Staab A, Leemans CR, Van Dongen GA. A phase I dose escalation study with anti-CD44v6 bivatuzumab mertansine in patients with incurable squamous cell carcinoma of the head and neck or esophagus. Clin Cancer Res. 2006;12: 6064-72.

94. Casucci M, Nicolis di Robilant B, Falcone L, Camisa B, Norelli M, Genovese P, Gentner B, Gullotta F, Ponzoni M, Bernardi M. CD44v6-targeted T cells mediate potent antitumor effects against acute myeloid leukemia and multiple myeloma. Blood. 2013;122:3461-72.

95. Carrabba MG, Casucci M, Hudecek M, Quintarelli C, Briones J, Hajek R, Sierra J, Locatelli F, Einsele H, Bordignon C. Phase I-lla clinical trial to assess safety and efficacy of MLM-CAR44. 1, a CD44v6 directed CAR-T in relapsed/ refractory acute myeloid leukemia (AML) and multiple myeloma (MM). Blood. 2018;132:5790.

96. Van Camp B, Durie B, Spier C, De Waele M, Van Riet I, Vela E, Frutiger $Y$, Richter L, Grogan TM. Plasma cells in multiple myeloma express a natural killer cell-associated antigen: CD56 (NKH-1; Leu-19); 1990.

97. Tassone P, Gozzini A, Goldmacher V, Shammas MA, Whiteman KR, Carrasco DR, Li C, Allam CK, Venuta S, Anderson KC. In vitro and in vivo activity of the maytansinoid immunoconjugate huN901-N2'-deacetyl-N2'-(3-mercapto1-oxopropyl)-maytansine against CD56+ multiple myeloma cells. Cancer Res. 2004;64:4629-36.

98. Ailawadhi S, Kelly KR, Vescio RA, Jagannath S, Wolf J, Gharibo M, Sher T, Bojanini L, Kirby M, Chanan-Khan A. A phase I study to assess the safety and pharmacokinetics of single-agent lorvotuzumab mertansine (IMGN901) in patients with relapsed and/or refractory CD-56-positive multiple myeloma. Clin Lymphoma Myeloma Leuk. 2019;19:29-34.

99. Berdeja JG. Lorvotuzumab mertansine: antibody-drug-conjugate for CD56+ multiple myeloma. Front Biosci (Landmark Ed). 2014;19:163-70.

100. Van Acker HH, Capsomidis A, Smits EL, Van Tendeloo VF. CD56 in the immune system: more than a marker for cytotoxicity? Front Immunol. 2017; 8:892.

101. Benjamin R, Condomines M, Gunset G, Sadelain M. CD56 targeted chimeric antigen receptors for immunotherapy of multiple myeloma. Cancer Res. 2012;72:3499.

102. McEarchern JA, Oflazoglu E, Francisco L, McDonagh CF, Gordon KA, Stone I, Klussman K, Turcott E, van Rooijen N, Carter P. Engineered anti-CD70 antibody with multiple effector functions exhibits in vitro and in vivo antitumor activities. Blood. 2007;109:1185-92.

103. Owonikoko TK, Hussain A, Stadler WM, Smith DC, Kluger H, Molina AM, Gulati P, Shah A, Ahlers CM, Cardarelli PM. First-in-human multicenter phase I study of BMS-936561 (MDX-1203), an antibody-drug conjugate targeting CD70. Cancer Chemother Pharmacol. 2016;77:155-62.

104. Tannir NM, Forero-Torres A, Ramchandren R, Pal SK, Ansell SM, Infante JR, De Vos S, Hamlin PA, Kim SK, Whiting NC. Phase I dose-escalation study of SGN-75 in patients with CD70-positive relapsed/refractory non-Hodgkin lymphoma or metastatic renal cell carcinoma. Investig New Drugs. 2014;32: 1246-57.

105. Wang QJ, Yu Z, Hanada K-i, Patel K, Kleiner D, Restifo NP, Yang JC. Preclinical evaluation of chimeric antigen receptors targeting CD70-expressing cancers. Clin Cancer Res. 2017;23:2267-76.

106. Ge H, Mu L, Jin L, Yang C, Chang Y, Long Y, DeLeon G, Deleyrolle L, Mitchell DA, Kubilis PS. Tumor associated CD70 expression is involved in promoting tumor migration and macrophage infiltration in GBM. Int J Cancer. 2017; 141:1434-44.

107. Jin L, Ge H, Long Y, Yang C, Chang Y, Mu L, Sayour EJ, De Leon G, Wang QJ, Yang JC. CD70, a novel target of CAR T-cell therapy for gliomas. NeuroOncol. 2018;20:55-65.

108. Shaffer DR, Savoldo B, Yi Z, Chow KK, Kakarla S, Spencer DM, Dotti G, Wu MF, Liu H, Kenney S. T cells redirected against CD70 for the immunotherapy of CD70-positive malignancies. Blood. 2011;117:4304-14.

109. Zheng W, Liu D, Fan X, Powers L, Goswami M, Hu Y, Lin P, Medeiros L, Wang SA. Potential therapeutic biomarkers in plasma cell myeloma: a flow cytometry study. Cytometry Part B: Clin Cytometry. 2013;84:222-8.

110. Sanderson RD, Turnbull JE, Gallagher JT, Lander AD. Fine structure of heparan sulfate regulates syndecan-1 function and cell behavior. J Biol Chem. 1994;269:13100-6.

111. Wijdenes J, Vooijs WC, Clément C, Post J, Morard F, Vita N, Laurent P, Sun RX, Klein B, Dore JM. A plasmocyte selective monoclonal antibody (B-B4) recognizes syndecan-1. Br J Haematol. 1996:94:318-23.

112. Moreaux J, Sprynski AC, Dillon SR, Mahtouk K, Jourdan M, Ythier A, Moine P, Robert N, Jourdan E, Rossi JF. APRIL and TACl interact with syndecan-1 on the surface of multiple myeloma cells to form an essential survival loop. Eur J Haematol. 2009:83:119-29.

113. Xu D, Hu J, Xu S, De Bruyne E, Menu E, Van Camp B, Vanderkerken K, Van Valckenborgh E. DII1/Notch activation accelerates multiple myeloma disease development by promoting CD138+ MM-cell proliferation. Leukemia. 2012; 26:1402-5.

114. Kambham $\mathrm{N}$, Kong $\mathrm{C}$, Longacre TA, Natkunam Y. Utility of syndecan-1 (CD138) expression in the diagnosis of undifferentiated malignant neoplasms: a tissue microarray study of 1,754 cases. Appli Immunohistochem Mol Morphol. 2005;13:304-10. 
115. Kawano Y, Fujiwara S, Wada N, Izaki M, Yuki H, Okuno Y, lyama K, Yamasaki $\mathrm{H}$, Sakai A, Mitsuya $\mathrm{H}$. Multiple myeloma cells expressing low levels of CD138 have an immature phenotype and reduced sensitivity to lenalidomide. Int J Oncol. 2012;41:876-84.

116. Jagannath S, Chanan-Khan A, Heffner LT, Avigan D, Zimmerman TM, Lonial S, Lutz RJ, Engling A, Uherek C, Osterroth F. BT062, an antibody-drug conjugate directed against CD138, shows clinical activity in patients with relapsed or relapsed/refractory multiple myeloma. Blood. 2011:118:305.

117. Kelly KR, Siegel DS, Chanan-Khan AA, Somlo G, Heffner LT, Jagannath S, Zimmerman T, Munshi NC, Madan S, Mohrbacher A. Indatuximab ravtansine (BT062) in combination with low-dose dexamethasone and lenalidomide or pomalidomide: clinical activity in patients with relapsed/refractory multiple myeloma. Blood. 2016;128:4486.

118. Jiang $H$, Zhang $W$, Shang $P$, Zhang $H$, Fu W, Ye F, Zeng $T$, Huang $H$, Zhang $X$, Sun W. Transfection of chimeric anti-CD138 gene enhances natural killer cell activation and killing of multiple myeloma cells. Mol Oncol. 2014;8:297310.

119. Guo B, Chen M, Han Q, Hui F, Dai H, Zhang W, Zhang Y, Wang Y, Zhu H, Han W. CD138-directed adoptive immunotherapy of chimeric antigen receptor (CAR)-modified T cells for multiple myeloma. J Cell Immunother. 2016;2:28-35.

120. Sun C, Mahendravada A, Ballard B, Kale B, Ramos C, West J, Maguire T, McKay K, Lichtman E, Tuchman S. Safety and efficacy of targeting CD138 with a chimeric antigen receptor for the treatment of multiple myeloma. Oncotarget. 2019;10:2369.

121. Ramani VC, Sanderson RD. Chemotherapy stimulates syndecan-1 shedding: a potentially negative effect of treatment that may promote tumor relapse. Matrix Biol. 2014;35:215-22.

122. Cannons JL, Tangye SG, Schwartzberg PL. SLAM family receptors and SAP adaptors in immunity. Ann Rev Immunol. 2011;29:665-705.

123. Malaer JD, Mathew PA. CS1 (SLAMF7, CD319) is an effective immunotherapeutic target for multiple myeloma. Am J Cancer Res. 2017;7:1637.

124. Chen J, Zhong M-C, Guo H, Davidson D, Mishel S, Lu Y, Rhee I, PérezQuintero L-A, Zhang S, Cruz-Munoz M-E. SLAMF7 is critical for phagocytosis of haematopoietic tumour cells via Mac-1 integrin. Nature. 2017;544:493-7.

125. Gogishvili T, Danhof S, Prommersberger S, Rydzek J, Schreder M, Brede C, Einsele $H$, Hudecek M. SLAMF7-CAR T cells eliminate myeloma and confer selective fratricide of SLAMF7+ normal lymphocytes. Blood. 2017;130:2838-47.

126. Hsi ED, Steinle R, Balasa B, Szmania S, Draksharapu A, Shum BP, Huseni M, Powers D, Nanisetti A, Zhang Y. CS1, a potential new therapeutic antibody target for the treatment of multiple myeloma. Clin Cancer Res. 2008;14:2775-84.

127. Veillette A, Guo H. CS1, a SLAM family receptor involved in immune regulation, is a therapeutic target in multiple myeloma. Crit Rev Onco Hematol. 2013;88:168-77.

128. De Salort J, Sintes J, Llinàs L, Matesanz-Isabel J, Engel P. Expression of SLAM (CD150) cell-surface receptors on human B-cell subsets: from pro-B to plasma cells. Immunol Lett. 2011;134:129-36.

129. Friend R, Bhutani M, Voorhees PM, Usmani SZ. Clinical potential of SLAMF7 antibodies-focus on elotuzumab in multiple myeloma. Drug Design Dev Ther. 2017;11:893.

130. Galetto R, Chion-Sotinel I, A. Gouble, J. Smith, Bypassing the constraint for chimeric antigen receptor (CAR) development in T-cells expressing the targeted antigen: improvement of anti-CS1 CAR activity in allogenic TCRa/ CS1 double knockout T-cells for the treatment of multiple myeloma (MM). Blood. 2015;126:116.

131. Tokarew N, Ogonek J, Endres S, von Bergwelt-Baildon M, Kobold S. Teaching an old dog new tricks: next-generation CAR T cells. Br J Cancer. 2019;120:26-37.

132. Mathur R, Zhang Z, He J, Galetto R, Gouble A, Chion-Sotinel I, Filipe S, Gariboldi A, Veeramachaneni T, Manasanch EE. Universal SLAMF7-specific CAR T-cells as treatment for multiple myeloma. Blood. 2017;130:502.

133. Wang X, Walter M, Urak R, Weng L, Huynh C, Lim L, Wong CW, Chang W-C, Thomas SH, Sanchez JF. Lenalidomide enhances the function of CS chimeric antigen receptor-redirected T cells against multiple myeloma. Clin Cancer Res. 2018;24:106-19.

134. Peinert S, Prince H, Guru P, Kershaw M, Smyth M, Trapani J, Gambell P, Harrison S, Scott A, Smyth F. Gene-modified T cells as immunotherapy for multiple myeloma and acute myeloid leukemia expressing the Lewis $Y$ antigen. Gene Ther. 2010;17:678-86.

135. Westwood JA, Smyth MJ, Teng MW, Moeller M, Trapani JA, Scott AM, Smyth FE, Cartwright GA, Power BE, Hönemann D. Adoptive transfer of T cells modified with a humanized chimeric receptor gene inhibits growth of Lewis-Y-expressing tumors in mice. Proc Natl Acad Sci. 2005;102:19051-6.

136. Lanier L. NKG2D receptor and its ligands in host defense. Cancer Immunol Res. 2015;3:575-82, in.

137. Nausch N, Cerwenka A. NKG2D ligands in tumor immunity. Oncogene. 2008:27:5944-58.

138. Zingoni A, Cecere F, Vulpis E, Fionda C, Molfetta R, Soriani A, Petrucci MT, Ricciardi MR, Fuerst D, Amendola MG. Genotoxic stress induces senescenceassociated ADAM10-dependent release of NKG2D MIC ligands in multiple myeloma cells. J Immunol. 2015;195:736-48.

139. Leivas A, Rio P, Mateos R, Paciello ML, Garcia-Ortiz A, Fernandez L, PerezMartinez A, Lee DA, Powell DJ, Valeri A. NKG2D-CAR transduced primary natural killer cells efficiently target multiple myeloma cells. Blood. 2018;132:590.

140. Baumeister SH, Murad J, Werner L, Daley H, Trebeden-Negre H, Gicobi JK, Schmucker A, Reder J, Sentman CL, Gilham DE. Phase 1 trial of autologous CAR T cells targeting NKG2D ligands in patients with AML/MDS and multiple myeloma. Cancer Immunol Res. 2019;7:100-12.

141. I. Borrello, P.H. Imus, BCMA CAR T cells: the winding path to success, J Clin Investig. 129 (2019)

142. Cohen AD, Garfall AL, Stadtmauer EA, Melenhorst JJ, Lacey SF, Lancaster E, Vogl DT, Weiss BM, Dengel K, Nelson A. B cell maturation antigen-specific CAR T cells are clinically active in multiple myeloma. J Clin Investig. 2019; 129:2210-2221.

143. L. Lee, B. Draper, N. Chaplin, B. Philip, M. Chin, D. Galas-Filipowicz, S. Onuoha, S. Thomas, V. Baldan, R. Bughda, An APRIL-based chimeric antigen receptor for dual targeting of $\mathrm{BCMA}$ and $\mathrm{TACl}$ in multiple myeloma, Blood, J Am Soc Hematol, 131 (2018) 746-758.

144. Maus MV, Haas AR, Beatty GL, Albelda SM, Levine BL, Liu X, Zhao Y, Kalos M, June $\mathrm{CH}$. T cells expressing chimeric antigen receptors can cause anaphylaxis in humans. Cancer Immunol Res. 2013;1:26-31.

145. Schmidts A, Ormhoj M, Taylor AO, Lorrey SJ, Scarfò I, Frigault MJ, Choi BD, Maus MV. Engineering an optimized trimeric APRIL-based CAR to broaden targetability of multiple myeloma. Blood. 2018;132:2059.

146. Tai Y-T, Lin L, Xing L, Cho S-F, Yu T, Acharya C, Wen K, Hsieh PA, Dulos J, van Elsas A. APRIL signaling via TACI mediates immunosuppression by T regulatory cells in multiple myeloma: therapeutic implications. Leukemia. 2019;33:426-38.

147. Venkateshaiah SU, Bam R, Li X, Khan S, Ling W, Randal S, Yaccoby S. GPRC5D Is a cell surface plasma cell marker whose expression is high in myeloma cells and reduced following coculture with osteoclasts. Blood. 2013;122:3099.

148. Cohen Y, Gutwein O, Garach-Jehoshua O, Bar-Haim A, Kornberg A. GPRC5D is a promising marker for monitoring the tumor load and to target multiple myeloma cells. Hematology. 2013;18:348-51.

149. Smith EL, Harrington K, Staehr M, Masakayan R, Jones J, Long T, Ghoddusi M, Purdon TJ, Do T, Wang X. CAR T cell therapy targeting G proteincoupled receptor class C group 5 member D (GPRC5D), a novel target for the immunotherapy of multiple myeloma. Blood. 2018;132:10.1182.

150. Frigyesi I, Adolfsson J, Ali M, Kronborg Christophersen M, Johnsson E, Turesson I, Gullberg U, Hansson M, Nilsson B. Robust isolation of malignant plasma cells in multiple myeloma. Blood. 2014;123:1336-40.

151. Smith EL, Harrington $K$, Staehr M, Masakayan R, Jones J, Long TJ, Ng KY, Ghoddusi M, Purdon TJ, Wang X. GPRC5D is a target for the immunotherapy of multiple myeloma with rationally designed CAR T cells. Sci Transl Med. 2019;11:eaau7746.

152. Hosen N, Matsunaga Y, Hasegawa K, Matsuno H, Nakamura Y, Makita M, Watanabe K, Yoshida M, Satoh K, Morimoto S. The activated conformation of integrin $\beta 7$ is a novel multiple myeloma-specific target for CAR T cell therapy. Nat Med. 2017;23:1436.

153. Spanoudakis E, Hu M, Naresh K, Terpos E, Melo V, Reid A, Kotsianidis I, Abdalla S, Rahemtulla A, Karadimitris A. Regulation of multiple myeloma survival and progression by CD1d. Blood. 2009;113:2498-507.

154. Rotolo A, Caputo VS, Holubova M, Baxan N, Dubois O, Chaudhry MS, Xiao X, Goudevenou K, Pitcher DS, Petevi K. Enhanced anti-lymphoma activity of CAR19-iNKT cells underpinned by dual CD19 and CD1d targeting. Cancer Cell. 2018;34:596-610. e511.

155. Muccio VE, Saraci E, Gilestro M, Gattei V, Zucchetto A, Astolfi M, Ruggeri M, Marzanati E, Passera R, Palumbo A. Multiple myeloma: new surface antigens for the characterization of plasma cells in the era of novel agents. Cytometry Part B: Clin Cytometry. 2016;90:81-90.

156. Olson M, Radhakrishnan SV, Luetkens T, Atanackovic D. The role of surface molecule CD229 in multiple myeloma. Clin Immunol. 2019;204:69-73. 
157. Yousef S, Kovacsovics-Bankowski M, Salama ME, Bhardwaj N, Steinbach M, Langemo A, Kovacsovics T, Marvin J, Binder M, Panse J. CD229 is expressed on the surface of plasma cells carrying an aberrant phenotype and chemotherapy-resistant precursor cells in multiple myeloma. Hum Vaccines Immunother. 2015;11:1606-11.

158. Venniyil Radhakrishnan S, Luetkens T, Yousef S, Bhardwaj N, Steinbach MN, Weidner J, Shorter C, Sborov DW, Atanackovic D. Chimeric antigen receptor (CAR) T cells specific for CD229: a potentially curative approach for multiple myeloma. Blood. 2017;130:3142.

159. Gardner R, Finney O, Smithers H, Leger KJ, Annesley CA, Summers C, Brown C, Mgebroff S, Lindgren C, Spratt K. CD19CAR T cell products of defined CD4: CD8 composition and transgene expression show prolonged persistence and durable MRD-negative remission in pediatric and young adult B-cell ALL. Blood. 2016;128:219.

160. Maude SL, Teachey DT, Rheingold SR, Shaw PA, Aplenc R, Barrett DM, Barker CS, Callahan C, Frey NV, Nazimuddin F. Sustained remissions with CD19specific chimeric antigen receptor (CAR)-modified T cells in children with relapsed/refractory ALL. J Clin Oncol. 2016;34:15_SUPPL.3011.

161. Hideshima T, Mitsiades C, Tonon G, Richardson PG, Anderson KC. Understanding multiple myeloma pathogenesis in the bone marrow to identify new therapeutic targets. Nat Rev Cancer. 2007;7:585-98.

162. Cazaux M, Grandjean CL, Lemaître F, Garcia Z, Beck RJ, Milo I, Postat J, Beltman JB, Cheadle EJ, Bousso P. Single-cell imaging of CAR T cell activity in vivo reveals extensive functional and anatomical heterogeneity. J Exp Med. 2019;216:1038-49.

163. Brimnes MK, Vangsted AJ, Knudsen LM, Gimsing P, Gang A, Johnsen HE, Svane I. Increased level of both CD4+ FOXP3+ regulatory T cells and CD14+ HLA-DR -/low myeloid-derived suppressor cells and decreased level of dendritic cells in patients with multiple myeloma. Scand J Immunol. 2010;72:540-7.

164. Feyler S, Von Lilienfeld-Toal M, Jarmin S, Marles L, Rawstron A, Ashcroft A, Owen RG, Selby PJ, Cook G. CD4+ CD25+ FoxP3+ regulatory T cells are increased whilst CD3+CD4-CD8- aßTCR+ double negative T cells are decreased in the peripheral blood of patients with multiple myeloma which correlates with disease burden. Bri J Haematol. 2009;144:686-95.

165. M. Majka, A. Janowska-Wieczorek, J. Ratajczak, K. Ehrenman, Z. Pietrzkowski, M.A. Kowalska, A.M. Gewirtz, S.G. Emerson, M.Z. Ratajczak, Numerous growth factors, cytokines, and chemokines are secreted by human CD34+ cells, myeloblasts, erythroblasts, and megakaryoblasts and regulate normal hematopoiesis in an autocrine/paracrine manner: presented at the 41st Annual Meeting of the American Society of Hematology, New Orleans, LA, December 3-7, 1999, and published in abstract form in Blood. 1999; 94 (suppl 1): 465a, Blood, The Journal of the American Society of Hematology, 97 (2001) 3075-3085.

166. Paul B, Kang S, Zheng Z, Kang Y. The challenges of checkpoint inhibition in the treatment of multiple myeloma. Cell Immunol. 2018;334:87-98.

167. D.L. Porter, N.V. Frey, J.J. Melenhorst, W.-T. Hwang, S.F. Lacey, P. Shaw, A. Chew, S.A. Grupp, J. Capobianchi, J. Gilmore, Randomized, phase II dose optimization study of chimeric antigen receptor modified T cells directed against CD19 (CTL019) in patients with relapsed, refractory CLL, in, American Society of Hematology Washington, DC, 2014.

168. Porter DL, Hwang W-T, Frey NV, Lacey SF, Shaw PA, Loren AW, Bagg A, Marcucci KT, Shen A, Gonzalez V. Chimeric antigen receptor T cells persist and induce sustained remissions in relapsed refractory chronic lymphocytic leukemia. Sci Transl Med. 2015;7:303ra139.

169. Davila ML, Riviere I, Wang X, Bartido S, Park J, Curran K, Chung SS, Stefanski J, Borquez-Ojeda O, Olszewska M. Efficacy and toxicity management of 19$28 z$ CAR T cell therapy in B cell acute lymphoblastic leukemia. Sci Transl Med. 2014;6:224ra225.

170. Binsfeld M, Muller J, Lamour V, De Veirman K, De Raeve H, Bellahcène A, Van Valckenborgh E, Baron F, Beguin Y, Caers J. Granulocytic myeloidderived suppressor cells promote angiogenesis in the context of multiple myeloma. Oncotarget. 2016;7:37931.

171. Görgün GT, Whitehill G, Anderson JL, Hideshima T, Maguire C, Laubach J, Raje N, Munshi NC, Richardson PG, Anderson KC. Tumor-promoting immune-suppressive myeloid-derived suppressor cells in the multiple myeloma microenvironment in humans. Blood. 2013;121:2975-87.

172. Parihar R, Rivas C, Huynh M, Omer B, Lapteva N, Metelitsa LS, Gottschalk SM, Rooney CM. NK cells expressing a chimeric activating receptor eliminate MDSCs and rescue impaired CAR-T cell activity against solid tumors. Cancer Immunol Res. 2019;7:363-75.

173. Helsen CW, Hammill JA, Lau WW, Mwawasi KA, Afsahi A, Bezverbnaya K, Newhook L, Hayes DL, Aarts C, Bojovic B. The chimeric TAC receptor co- opts the T cell receptor yielding robust anti-tumor activity without toxicity. Nat Commun. 2018:9:1-13.

174. Lamers CH, Sleijfer S, Vulto AG, Kruit WH, Kliffen M, Debets R, Gratama JW, Stoter G, Oosterwijk E. Treatment of metastatic renal cell carcinoma with autologous T-lymphocytes genetically retargeted against carbonic anhydrase IX: first clinical experience. J Clin Oncol. 2006;24:e20-2.

175. Morgan RA, Yang JC, Kitano M, Dudley ME, Laurencot CM, Rosenberg SA. Case report of a serious adverse event following the administration of T cells transduced with a chimeric antigen receptor recognizing ERBB2. Mol Ther. 2010;18:843-51.

176. Gargett T, Brown MP. The inducible caspase- 9 suicide gene system as a "safety switch" to limit on-target, off-tumor toxicities of chimeric antigen receptor T cells. Front Pharmacol. 2014;5:235.

177. Chen YY, Jensen MC, Smolke CD. Genetic control of mammalian T-cell proliferation with synthetic RNA regulatory systems. Proc Natl Acad Sci. 2010;107:8531-6.

178. Wei P, Wong WW, Park JS, Corcoran EE, Peisajovich SG, Onuffer JJ, Weiss A, Lim WA. Bacterial virulence proteins as tools to rewire kinase pathways in yeast and immune cells. Nature. 2012;488:384-8.

179. Vogler I, Newrzela S, Hartmann S, Schneider N, Von Laer D, Koehl U, Grez M. An improved bicistronic CD20/tCD34 vector for efficient purification and in vivo depletion of gene-modified T cells for adoptive immunotherapy. Mol Ther. 2010;18:1330-8.

180. Wang X, Chang W-C, Wong CW, Colcher D, Sherman M, Ostberg JR, Forman SJ, Riddell SR, Jensen MC. A transgene-encoded cell surface polypeptide for selection, in vivo tracking, and ablation of engineered cells. Blood. 2011;118: 1255-63.

181. Wu C-Y, Roybal KT, Puchner EM, Onuffer J, Lim WA. Remote control of therapeutic T cells through a small molecule-gated chimeric receptor. Science. 2015;350:aab4077.

182. Fedorov VD, Themeli M, Sadelain M. PD-1-and CTLA-4-based inhibitory chimeric antigen receptors (iCARs) divert off-target immunotherapy responses. Sci Transl Med. 2013;5:215ra172.

183. Grigor EJM, Fergusson D, Kekre N, Montroy J, Atkins H, Seftel MD, Daugaard M, Presseau J, Thavorn K, Hutton B, Holt RA, Lalu MM. Risks and benefits of chimeric antigen receptor T-cell (CAR-T) therapy in cancer: a systematic review and meta-analysis. Transfusion Med Rev. 2019;33:98-110.

184. Grada Z, Hegde M, Byrd T, Shaffer DR, Ghazi A, Brawley VS, Corder A, Schönfeld K, Koch J, Dotti G. TanCAR: a novel bispecific chimeric antigen receptor for cancer immunotherapy. Mol Ther -Nucleic Acids. 2013;2:e105.

185. Kloss CC, Condomines M, Cartellieri M, Bachmann M, Sadelain M. Combinatorial antigen recognition with balanced signaling promotes selective tumor eradication by engineered T cells. Nat Biotechnol. 2013;31:71.

186. Lanitis E, Poussin M, Klattenhoff AW, Song D, Sandaltzopoulos R, June CH, Powell DJ. Chimeric antigen receptor $T$ cells with dissociated signaling domains exhibit focused antitumor activity with reduced potential for toxicity in vivo. Cancer Immunol Res. 2013;1:43-53.

187. Wilkie S, van Schalkwyk MC, Hobbs S, Davies DM, van der Stegen SJ, Pereira ACP, Burbridge SE, Box C, Eccles SA, Maher J. Dual targeting of ErbB2 and MUC1 in breast cancer using chimeric antigen receptors engineered to provide complementary signaling. J Clin Immunol. 2012;32:1059-70.

188. Sommer C, Boldajipour B, Kuo TC, Bentley T, Sutton J, Chen A, Geng T, Dong H, Galetto R, Valton J. Preclinical evaluation of allogeneic CAR T cells targeting BCMA for the treatment of multiple myeloma. Mol Ther. 2019;27: $1126-38$.

\section{Publisher's Note}

Springer Nature remains neutral with regard to jurisdictional claims in published maps and institutional affiliations. 